\title{
Work Management Administration FY 1995 Site Support Program Plan WBS 6.2
}

\author{
N. S. Hale \\ Date Published \\ September 1994
}

Prepared for the U.S. Department of Energy

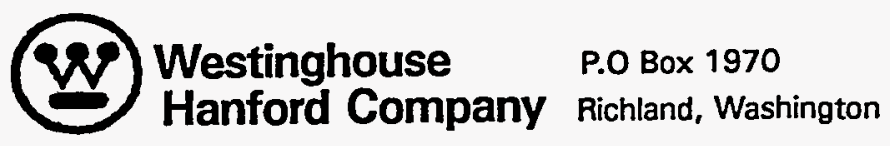

Hanford Operations and Engineering Contractor for the

U.S. Department of Energy under Contract DE-AC06-87RL10930

Approved for Public Release 
LECAL DISCLAMER.

This report was prepared as an account of work sponsored by an agency of the United States Government. Neither the United States Government nor any agency thereof, nor any of their employees, nor any of their contractors, subcontractors or their employees, makes any warranty, express or implied, or assumes any legal liability or responsibility for the accuracy, completeness, or any third party's use or the results of such use of any information, apparatus, product, or process disclosed, or represents that its use would not infringe privately owned rights. Reference herein to any specific commercial product, process, or service by trade name, trademark, manufacturer, or otherwise, does not necessarily constitute or imply its endorsement, recommendation, or favoring by the United States Government or any agency thereof or its contractors or subcontractors. The views and opinions of euthors expressed herein do not necessarily state or reflect those of the United States Government or any agency thereof.

This report has been reproduced from the best aveilable copy. Available in paper copy and microfiche.

Available to the U.S. Department of Energy and its contractors from

Office of Scientific and Technical Information

P.O. Box 62

Oak Ridge, TN 37831

(615) $576-8401$

Printed in the United States of Americe

DISCLM-3.CHP (1-91) 


\section{DISCLAIMER}

Portions of this document may be illegible in electronic image products. Images are produced from the best available original document. 


\section{RELEASE AUTHORIZATION}

Document Number: $\quad$ HHC-SP-1127

Document Title: Work Management Administration FY 1995 Site Support Program Plan WBS 6.2

Release Date: $\quad 9 / 8 / 94$

This document was reviewed following the procedures described in WHC-CM-3-4 and is:

APPROVED FOR PUBLIC RELEASE

* * * * * * * * * * * * *

WHC Information Release Administration Specialist:

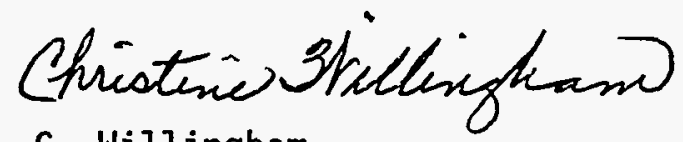

C. Witl ingham (Signature) 9/8/94 (Date) 


\section{Site Support Program Plan Approval Sheet}

\section{WBS 6.2 Work Management Administration}

NOTE: Because of funding reductions Site-wide, this Site Support Program Plan is not being approved for fult funding. Several scopes of work identified in this plan will be affected. Specific work scope impacts, along with revised Work Breakdown Structure Dictionaries, are found in Section 4.0 of this document. If full funding is approved during FY 1995, Section $4.0^{\circ}$ of this document will be voided and the original plan will not require further modification.

\section{Assistant Manager-Contracting Officer's Representative}

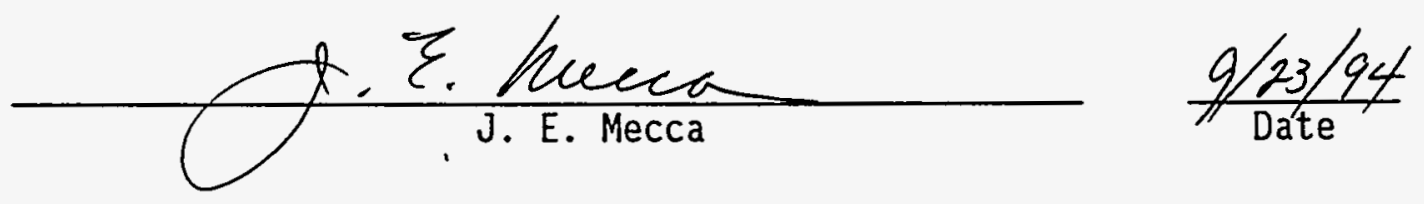

RL Program Manager

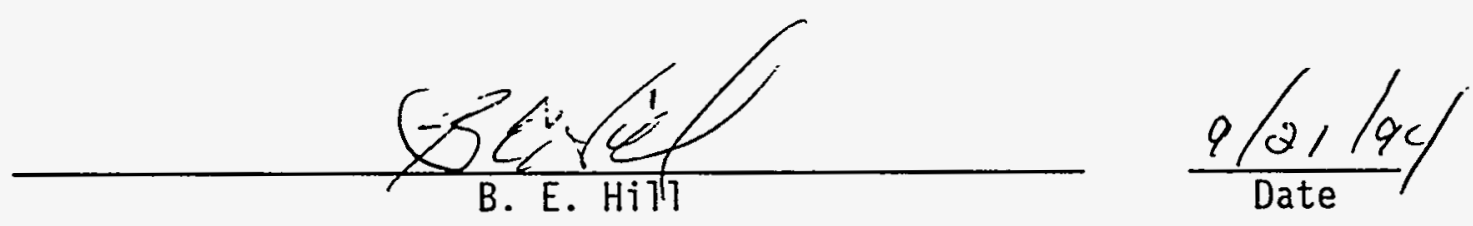

WHC Program Manager

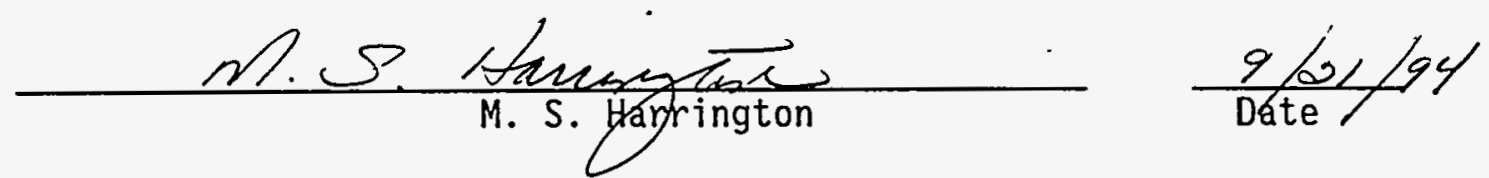




\section{CONTENTS}

1.0 OVERVIEW ........................ 1

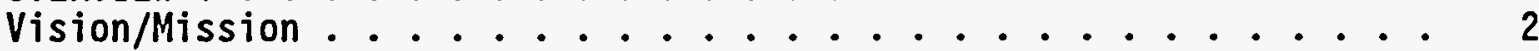

Internal Assessment Summary ............... 3

Primary Customers .............. 3

Products/Services Provided . . . . . . . . . . 3

Major Activities Performed to Deliver Products and Services . . 4

Evaluation of Major Activities (cost, value-added, etc.) ... 5

Factors Which Influence Resource Consumption (changes to

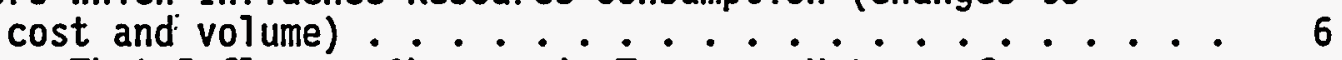

Factors That Influence Changes in Types or Nature of Products and Services .............. 6

External Assessment Summary ................. 7

Goals and Objectives................... 8

objective 1..................... 8

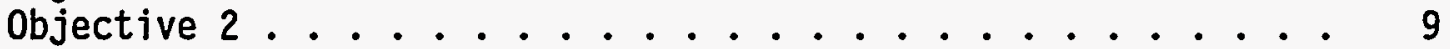

objective $3 \ldots \ldots \ldots 10 \ldots \ldots$

Objective $4 \ldots \ldots \ldots \ldots 11$

Objective $5 \ldots \ldots \ldots \ldots$

objective $6 \ldots \ldots \ldots \ldots 12 \ldots \ldots \ldots$

Objective $7 \ldots \ldots \ldots \ldots \ldots$

Objective $8 \ldots \ldots \ldots \ldots$

Strategies ................... 14

Customer Support Strategies . . . . . . . . . . 14

Production Strategies ......................... 14

Organization and Management Strategies ......... 14

Assumptions ................. 15

Issues and Constraints ................. 17

Performance Measures ................ 18

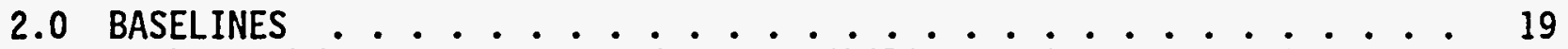

Work Breakdown Structure and Responsibility Assignment Matrix . . 20

Description of Activities ............... 21

Milestone List . . . . . . . . . . . . . . . . . 28

Cost Basel ine by Program Element .............. 29

Cost Basis .................... 31

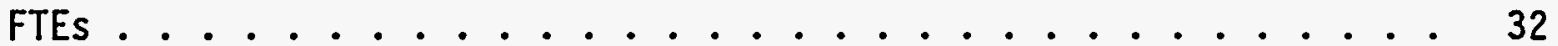

3.0 EXECUTION YEAR PACKAGE $\ldots \ldots \ldots+\cdots$

Work Breakdown Structure Dictionary for WBS 6.2.1, Work Management . 36

Addendum to Work Breakdown Structure Dictionary . . . . . . . 39

Work Breakdown Structure Dictionary for WBS 6.2.2, Job Contro1

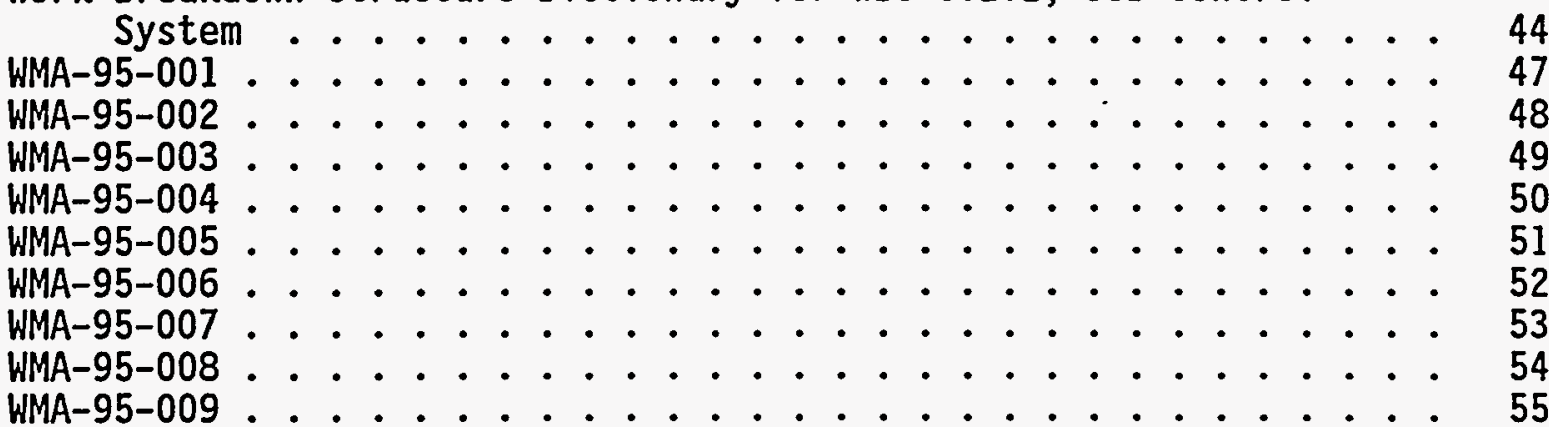




\section{CONTENTS (cont)}

4.0 TARGETED FUNDING IMPACTS TO PLANNED ACTIVITIES . . . . . . . . . 56

Targeted Funding Program Impacts . . . . . . . . . . . . . 57

\section{LIST OF FIGURES}

2-1 Work Breakdown Structure (6.2--Work Management Administration) . . . 23

2-2 Work Breakdown Structure (6.2.1.1--Performance Improvements/ Implementation) ....................... 24

2-3 Work Breakdown Structure (6.2.1.2--Documentation) . . . . . . . 25

2-4 Work Breakdown Structure (6.2.1.3--Training) . . . . . . . . . 26

2-5 Work Breakdown Structure (6.2.2--Job Control System) . . . . . . 27 


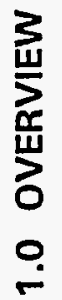




\begin{tabular}{|l|c|c|}
\hline 1.A Vision/Mission & $\begin{array}{c}\text { Westinghouse Hanford Company } \\
\text { Work Management Administration } \\
\text { SMS/WBS } 6.2\end{array}$ & $\begin{array}{c}\text { FY 1995 } \\
\text { Site Support Program Plan } \\
\text { Date Prepared: } 8 / 15 / 94\end{array}$ \\
\hline
\end{tabular}

\section{Vision/Mission:}

Work management at the Hanford Site must comply with federal regulations. The work management process must foster a safe working environment and be protective of the environment and the public. Further, work management at Hanford should be cost effective, consistent with industry practices, and control work using a graded approach.

Westinghouse Hanford Company's (WHC) near-term vision is to implement a Site-wide work management program that is consistent from one facility to the other, and can realize workforce efficiencies, minimum down time, and familiarization with facilities uniqueness. Additionally, consistent Hanford Site work management processes can produce meaningful information to be shared complex-wide as the U.S. Department of Energy (DOE) cleans up facilities Site-wide.

\section{Specific Mission Statements:}

\section{Work Management}

It is the mission of the WHC Hork Management Administration Program to provide guidance and program direction on how to implement consistent and effective work management across the Hanford Site that comply with the DOE and other regulatory requirements.

\section{Job Control System}

The mission of the JCS Support group is to monitor and maintain JCS software and network performance in a stable and reliable manner. This group also manages hardware and software upgrades/replacements to ensure optimum operation and provides the necessary checks and balances in the system to ensure quality assurance software and security specifications are met. The JCS support group is responsible for data conversion in support of preventive maintenance and equipment history module implementation. 


\section{B.1 Internal Assessment} Summary
- Westinghouse Hanford Company Work Management Administration SMS/WBS 6.2
FY 1995

Site Support Program Plan Date Prepared: 8/15/94

NOTE: This assessment summary is for both internal and external assessments. What follows is the result of a facilitated session with RL and program personnel.

\section{Primary Customers}

The primary customers supported by this program are: Maintenance and Operations personnel in the U.S. Department of Energy-Headquarters and RL Offices, Westinghouse Hanford Company direct funded programs/projects, and operating nuclear and non-nuclear facilities.

\section{Products/Services Provided}

Administer the work management process.

- Provide Site personnel with interpretation of DOE Order 4330.4B, Maintenance Management.

- Provide leadership in developing and employing standards and methods for maintenance practices as prescribed in DOE Order $4330.4 \mathrm{~B}$ (e.g., workmanship standards and engineered performance standards [EPS]).

- Provide guidance and mentoring of Site personnel in work management.

- Provide leadership in work management issues resolution.

- Coordinate and help develop training for the work management process to assure compliance with WHC-CM-1-8 Work Management and DOE Order 4330.4B.

- Continually improve the work management process and reflect the improvements in the WHC-CM-1-8, Work Management manual in support of our customers.

- Coordinate and author the Site Maintenance Plan for non-nuclear facilities.

- Provide guidance on the development of the Maintenance and Implementation Plans (M\&IP) required by 10 CFR 830.340 for nuclear facilities. 
- Coordinate submission of Davis-Bacon Plant Forces Work Review documents to the RL Labor Standards Board.

- Oversee the Davis-Bacon Act compliance process, providing assistance and training to field personnel to aid in compliance.

- Coordinate reporting of Site-wide measurements of the work management process.

Administer Job Control System.

- Provide JCS network maintenance and hardware/software upgrades.

- Ensure that system quality assurance and security standards are met.

- Evaluate commercial work management products for jCS network operability and compatability with respect to strategic pians for the computer network.

- Troubleshoot and correct any operational problems that occur in JCS network use.

Major Activities Performed to Deliver Products and Services

NOTE: These activities are not segregated under work management and JCS headers because many of them involve efforts of both groups.

Acquisition and administration of consultant contracts to provide specialized technical expertise to support implementing work management requirements in DOE Order 4330.4B. Consultants provide guidance in the areas of work management, conduct of maintenance, conduct of operations, and scheduling.

Perform document analysis and publish Site-wide guidance and technical manuals to ensure administrative compliance with regulatory requirements that interface with the work management process. of the JCS.

Acquisition, installation and maintenance of computer hardware and software to support daily operations

Perform annually, fiscal year (FY) work planning to establish current and out-year work scope and fiscal requirements for the program.

Resolve work management issues which cross functional or company boundaries. 
Coordinate the implementation of the preventive maintenance/surveillance and equipment history modules.

Review and coordinate information required on Davis-Bacon Plant Forces Work Reviews prior to submittal to the RL Labor Standards Board.

Perform training on the Davis-Bacon Act and the company compliance process.

Evaluation of Major Activities (cost, value-added, etc.)

Major costs associated with contract acquisition and administration comes from the contracts themselves. The benefit derived from contracting specialty services has been and is primarily one of retaining services not readily available within the program. Monitoring of contract services proved effective in improving management infrastructure during FY 1994 and further gains are expected in FY 1995.

Major costs associated with document analysis and publishing guidance come from the program personnel who perform the reviews and develop guidance. Value added comes from assurance that the work management process complies with regulatory requirements and provides a uniform application of the work management process across the Site.

Major costs associated from JCS maintenance activities are primarily derived from personnel costs associated with contracting BCS Richland, Inc. (BCSR) to maintain reliability, operability, quality and security of the JCS. Some hardware costs are also associated with this activity as fileservers are replaced or equipment is repaired. The value added from this activity is reliable, secure operations of the JCS network, timely response to any network problems, and installation of only compatible hardware and software.

Program planning is an annual effort and costs for this activity includes time spent by personnel in facilitated sessions, cost of the facilitator, and costs associated with developing the planning document. Included in these costs are personnel time used to prepare monthly site management system reports. The value added by this activity is a high quality program with specific program deliverables that meet or exceed the customer expectations, and documented methods that can be used to achieve the program's objectives.

Costs for resolving work management issues are derived primarily from personnel involvement. The cost of this activity varies widely as the Hanford Site mission changes and different issues are raised. The benefit of centrally resolving issues is that site-wide issues are resolved more cost effectively. 
Implementation of the preventive maintenance/surveillance and equipment history JCS modules is a one time cost shared with participating facilities. The cost to the Work Management Administration program come from funding personnel who makes conversions and help with implementation coordination activities and training.

The Davis-Bacon Act compliance process derives its cost from personnel involvement. This process, while costly, is in direct support of the contract since flagrant violation of the Act can result in loss of the contract and inability to re-bid DOE and U.S. Department of Defense contracts (worldwide) for three years.

\section{Factors Which Influence Resource Consumption (changes to cost and volume)}

The major factors that influence resource consumption are:

- Changes in governing requirements

- Changes in training demands

- Internal and external shifts in strategic direction to support RL objectives and expectations

- Reorganizations

- Changes to the customer base

- Changes in reporting requirements

- Emergent work.

\section{Factors That Influence Changes in Types or Nature of Products and Services}

The major factors that influence the type or nature of products are:

- Loss of funding

- Changes in requirements

- Added work scope

- Commercialization of the work management process administration

- Shifts in strategic direction (internal and external)

- Reassignment of organizational roles and responsibilities. 


\begin{tabular}{|l|c|c|}
\hline 1.B.2 External Assessment Summary & $\begin{array}{c}\text { Westinghouse Hanford Company } \\
\text { Work Management Administration } \\
\text { SMS/WBS No. 6.2 }\end{array}$ & $\begin{array}{c}\text { FY } 1995 \\
\text { Site Support Program Plan } \\
\text { Date Prepared: } 8 / 15 / 94\end{array}$ \\
\hline
\end{tabular}

\section{SUMMARY OF CUSTOMER REQUIREMENTS (NEEDS)}

See Note for Internal Assessment Summary 


\begin{tabular}{|l|c|c|}
\hline 1.C Goals and Objectives & $\begin{array}{c}\text { West inghouse Hanford Company } \\
\text { Work Management Administration } \\
\text { SMS/WBS No. 6.2 }\end{array}$ & $\begin{array}{c}\text { FY 1995 } \\
\text { Site Support Program Plan } \\
\text { Date Prepared:8/15/94 }\end{array}$ \\
\hline
\end{tabular}

\section{Objective 1}

Define process and measurements needed to implement work management.

Goals

1. Take leadership role in establishing EPSs

a. Obtain services of Naval Facilities Engineering Command (NAVFAC) to adopt their standards

b. Develop an implementation plan for adopting NAVFAC EPS

- Tailor EPS to individual plants

- Integrate EPS with workmanship standards

- Incorporate EPS factors into training

2. Take leadership role in establishing workmanship standards

a. Issue workmanship standards (issue a quarterly update)

b. Coordinate training for using workmanship standards

c. Establish consistent Site training of workmanship standards

3. Establish guidance for work scheduling that fulfills program objectives and publish work scheduling methods in a Site-wide manual

a. Establish an integrated priority system meaningful to Site operations

b. Establish an effective work management scheduling system for the Site

c. Run a pilot program in Tank Waste Remediation Systems and publish lessons learned

- d. Assist in developing a method for collecting the cost of developing work packages

4. Establish guidance for developing uniform plant M\&IPs for nuclear facilities

a. Publish guidance for the M\&IPs, with plant involvement

b. Incorporate guidance for using Safety Equipment Lists (SEL) and Master Equipment Lists (MEL) 
5. Incorporate SEL and MEL guidance into WHC-CM-1-8, Work Management

6. Coordinate Site-wide performance measurement reporting for maintenance organizations.

7. Update Part 2 of the Site Maintenance Plan for 1995 maintenance activities.

- Prepare FY 1997 Infrastructure and Maintenance budget request (formerly the Maintenance and Repair Cross-Cut budget).

8. Define standards and develop procedures for equipment history (fault codes for equipment failure).

9. Implement a single form to initiate work in the work management process, and a single form for releasing work in the facilities.

10. Investigate benefits of incorporating the radiation work permit and the lock and tag procedures into the HHC-CM-1-8 manual.

\section{Objective 2}

Define the training needed to communicate the work management process.

Goals

1. Extend the Kappes Consulting contract through September 1995 for training and mentoring

a. Write a specific, defined fundamentals-based agenda for Kappes to use during the mentoring phase.

- Supervisor time in the field

- Establish optimum performance objectives

- Track pre-release process delays

- Track post-release suspension rate

- Track adherence to the schedule

- Track post-acceptance package delays for work packages associated with an engineering change notice or a drawing change 
2. Ensure the basic scheduler training needs are met

a. Review Project Software and Development, Inc. (PSDI) scheduler training results

- Extend PSDI consulting contract if results are acceptable

- Replace the PSDI contract if results are not acceptable

3. Provide Davis-Bacon training

a. Make the computer-based training course (in ToolBook ) available to Site on Davis-Bacon fileserver

b. Write the desk instruction for preparing plant forces work reviews

c. Add new examples of plant forces work reviews to those already available on the Davis-Bacon fileserver

d. Expand the Area Work Review Agent (AWRA) base to include: Radio Maintenance, Security Maintenance, BCSR Maintenance, Projects and Facilities Management, and Telecommunications.

- Get AWRAs assigned

- Train new AWRAs

4. Continue work management training, coordinated with the technical training organization.

5. Develop training for the JCS equipment history module.

\section{Objective 3}

Provide mentoring on work management for work control centers.

Goals

1. Provide personnel (mentors) to advise facility work management personnel on work management issues

a. Review work package scope and help to optimize work package processing by further reducing the number of reviews/approvals and forms

b. Provide guidance on how to increase pre-approved work packages and processes 
c. Communicate "lessons learned" through benchmarking activities observed from facility to facility.

\section{Objective 4}

Document the work management process.

\section{Goals}

1. Objective 1, Goal 1.b applies. (Develop an implementation plan for adopting NAVFAC EPS

- Tailor EPS to individual plants

- Integrate EPS with workmanship standards

- Incorporate EPS factors into training)

2. Evaluate the WHC-CM-8-7 manual and incorporate Site-wide applications into the WHC-CM-1-8 manual.

- Determine which portions of the manual should reside in other manuals and coordinate their placement through the Work Management Sub-Council

3. Obtain feedback from the work management training provided by Kappes Consulting. Evaluate the feedback for items to incorporate into the WHC-CM-1-8 manual.

4. Objective 2, Goal 1.a applies. (Write a specific, defined fundamentals-based agenda for Kappes to use during the mentoring phase

- Supervisor time in the field

- Estabiish optimum performance objectives

- Track pre-release process delays

- Track post-release suspension rate

- Track adherence to the schedule

- Track post-acceptance package delays for work packages associated with an engineering change notice or a drawing change)

5. Objective 1, Goal 4 applies. (Establish guidance for developing a uniform plant M\&IP for nuclear facilities

a. Publish standardized boiler plate for M\&IPs with plant involvement

b. Incorporate guidance for using SELs and MELs) 
6. See Objective 1, Goal 8. (Define standards and develop procedures for equipment history (fault codes for equipment failure).) Revise the WHC-CM-1-8 manual according to results of the referenced goal.

\section{Objective 5}

Resolve work management issues raised in FY 1995.

Goals

Since this scope of work is highly variable, the only goal that can be planned for is customer satisfaction in resolution of work management issues.

\section{Objective 6}

Continue implementation of the JCS preventive maintenance/surveillance and equipment history modules. Goal

Publish the schedule for implementing the JCS preventive maintenance/surveillance module.

\section{Objective 7}

Seek replacement of the present JCS software program with a commercial work management program.

$\underline{\text { Goals }}$

1. Establish the minimum operating criteria for a work management computer program to meet Site needs.

2. Compare commercial software package (Maximo) to criteria.

3. Make recommendation to pilot Maximo software based on its capability to meet minimum operating criteria.

4. Pilot the Maximo software package based on items 1-3.

5. Review open market work management products for alternative if Maximo is found to be functionally inadequate and pursue steps 1-4 to select a replacement software. 


\section{Objective 8}

Continue support of the JCS until a more cost-effective work management software product can be identified, tested, and implemented.

\section{Goa7s}

1. Provide data conversions for the JCS preventive maintenance/surveillance module implementation.

2. Monitor, repair, and troubleshoot the JCS (hardware and software), and provide production support.

3. Provide minor enhancements to the JCS.

4. Develop a third party scheduling interface with the JCS scheduling tool.

5. Install new fileservers to ensure system reliability. 


\begin{tabular}{|l|c|c|}
\hline 1.D Strategies & $\begin{array}{c}\text { Westinghouse Hanford Company } \\
\text { Work Management Administration } \\
\text { SMS/WBS No. } 6.2\end{array}$ & $\begin{array}{c}\text { FY } 1995 \\
\text { Site Support Program P1an } \\
\text { Date Prepared: } 8 / 15 / 94\end{array}$ \\
\hline
\end{tabular}

\section{Customer Support Strategies}

Customer support strategies are designed to identify customer needs. Once customer needs are identified, the follow-on action is to develop methods to meet those needs. The primary tools used to perform these two tasks are facilitated sessions (WesTIP, or Value Engineering Study), less formal facilitated sessions, user group meetings for JCS users, and continual contact with the customers.

\section{Production Strategies}

Production strategies involve:

1. Ensuring adequate support and sponsorship prior to investing extensive efforts or funds into a project

2. Project control adequate for the complexity of the specific task

3. Reporting progress to customers to ensure continued support.

\section{Organization and Management Strategies}

In response to the dual level of expectations placed on this program i.e., field support and administrative support, staff associated with this program have been divided into two teams. One team provides direct customer interface and support to facilities in the areas of work management implementation and JCS use. The other team is dedicated to providing administrative support in the form of work management process improvements, up-to-date manuals and direction, Site-wide issues resolution, JCS network maintenance, and other "behind-the-scenes" tasks that make field work easier.

The two teams work closely together to focus on continuous improvement of the work management process for customers in the field, while meeting our RL customer expectations. Key to this dual role is the "cross-pollination" of good work practices between facilities and incorporation of industry standards into the work management process at Hanford. 


\section{E Assumptions}

Westinghouse Hanford Company Work Management Administration SMS/WBS No.
FY 1995

Site Support Program Plan Date Prepared: 8/15/94

The following list contains both general and specific assumptions. The numbering scheme refers to the objectives and goals section of this plan (e.g., objective \#.goal \#). The general assumptions are numbered with a G.\# simply for reference in this section.

\section{General Assumptions}

G.1 Maintenance Programs Integration will remain responsible for defining the work management process, its training requirements, and for providing facilities with work management expertise.

G.2 Maintenance Programs Integration will remain responsible for defining the JCS, its training requirements, administration, and for providing facilities with JCS expertise.

G.3 The Site Procedures group will maintain responsibility for interfacing with user groups relative to statutory permits.

G.4 Completion/closure of work packages is the responsibility of the facility owners/managers.

G.5 Work management will continue to improve at a pace that will allow this program to dissolve in FY 1997.

Specific Assumptions (First \# refers to objective and second \# refers to goal)

1.1 Customer support for implementing EPSs will continue throughout the implementation effort.

1.1 Naval Facilities Engineering Command personnel will be available to support implementation of EPS.

1.1 We can use a high percentage of the material developed by NAVFAC for ICF KH.

1.2 There will be continued support and funding for developing workmanship standards.

1.2 There will be continued matrixed support from Procedures Development, Tank Waste Remediation Services Technical Training, and the Crafts organizations.

1.3 There will be enough support to drive development of an integrated priority system and scheduling system into a Site-wide manual.

1.3 There will be a sponsor to pilot a priority and scheduling system.

1.3 The Hork Management Sub-Council will sponsor FY 1996 implementation of an integrated priority system and scheduling system.

1.4 See G.1

1.5 See G.1

1.6 See G.1

1.7 Maintenance Programs Integration will be responsible for updating the Site Maintenance Plan, Part 2.

1.8 See G.1 
1.9 There will be continued customer support for a single work form to initiate work in the work management process.

1.9 There will be continued customer support to adopt a single work release form methodology.

1.10 Inclusion of the radiation worker permit and lock and tag procedures into the WHC-CM-1-8 manual will streaml ine the work management process.

1.10 The Environmental, Safety, and Quality Assurance manager will concur with moving the radiation worker permit and lock and tag procedures into the HHC-CM-1-8 manual.

2.1 Kappes Consulting will be available to support work management implementation through September 1995.

2.2 See G.1

2.2 Basic Scheduler training contractors will continue to be available.

2.3 Groups targeted to assign Area Work Review Agents will support their assignment."

2.4 See G.1

2.5 See G.2

3 See G.1

4.1 See 1.1

4.2 There will be elements of the 01d WHC-CM-8-7 manual that will need to be included in the WHC-CM-1-8 manual.

4.3 See G.1

4.4 See 2.1

4.5 Organization changes and changes to the way WHC does business will prompt a revision of the present Site Maintenance Plan, Part 1 .

4.6 See G.1

4.7 See G.1

4.8 See G.1

5 See G.1

6 See G.2

7.1 See G.1

7.2 Previous market research into JCS replacement software is adequate based on the software specifications document.

7.3 The Maximo program produced by PSDI will adequately replace the JCS within the existing network infrastructure.

7.3 The Maximo program can be readily obtained for a tank waste remediation systems pilot program. 


\begin{tabular}{|l|c|c|}
\hline 1.F Issues and Constraints & $\begin{array}{c}\text { Westinghouse Hanford Company } \\
\text { Work Management Administration } \\
\text { SMS/WBS No. 6.2 }\end{array}$ & $\begin{array}{c}\text { FY 1995 } \\
\text { Site Support Program Plan } \\
\text { Date Prepared: } 8 / 15 / 94\end{array}$ \\
\hline
\end{tabular}

Any item on the list of assumptions could conceivably become an issue and constrain the program. The Hork Management Administration program has the potential to be constrained if RL, DOE HQ, or congress opted to remove support for the Hanford Site program. 


\begin{tabular}{|l|c|c|}
\hline $1 . G$ Performance Measures & $\begin{array}{c}\text { Westinghouse Hanford Company } \\
\text { Work Management Administration } \\
\text { SMS/WBS No. } 6.2\end{array}$ & $\begin{array}{c}\text { FY } 1995 \\
\text { Site Support Program Plan } \\
\text { Date Prepared: } 8 / 15 / 94\end{array}$ \\
\hline
\end{tabular}

Performance of this program will be measured in the following ways:

1. Customer surveys responding to training effectiveness and direct support.

2. Regular interface meetings with RL.

3. Benchmarking the JCS program and Maximo (the anticipated replacement for JCS) against other commercially available software and industry standards for maintenance.

4. Production of milestones and deliverables on time or ahead of schedule.

5. Continued exemplary safety record. 


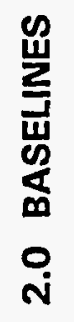


WHC-SP-1127

\begin{tabular}{|c|c|c|c|c|c|}
\hline \multicolumn{2}{|c|}{$\begin{array}{l}\text { 2.A.1 Work Breakdown Structure and } \\
\text { Responsibility Assignment Matrix }\end{array}$} & \multicolumn{2}{|c|}{$\begin{array}{l}\text { Westinghouse Hanford Company } \\
\text { Work Management Administration } \\
\text { SMS/WBS No. } 6.2\end{array}$} & \multicolumn{2}{|c|}{$\begin{array}{l}\text { FY } 1995 \\
\text { Site Support Program Plan } \\
\text { Date Prepared: } 8 / 15 / 94\end{array}$} \\
\hline Program Element & $\begin{array}{c}\text { Activity/Program } \\
\text { Sub-ET ement }\end{array}$ & Cost Account & Title & $\begin{array}{l}\text { Responsible } \\
\text { Manager }\end{array}$ & $\begin{array}{c}\text { Responsible } \\
\text { Organization }\end{array}$ \\
\hline \multirow[t]{3}{*}{6.2 .1} & 6.2 .1 .1 & 1MDKOA & $\begin{array}{l}\text { Work Management } \\
\text { Process } \\
\text { Improvements }\end{array}$ & $\begin{array}{l}\text { M. S. } \\
\text { Harrington }\end{array}$ & $\begin{array}{l}\text { Maintenance } \\
\text { Programs } \\
\text { Integration }\end{array}$ \\
\hline & 6.2 .1 .2 & & $\begin{array}{l}\text { Work Management } \\
\text { Documentation }\end{array}$ & & \\
\hline & 6.2 .1 .3 & & $\begin{array}{l}\text { Work Management } \\
\text { Training }\end{array}$ & & \\
\hline \multirow[t]{2}{*}{6.2 .2} & 6.2 .2 .1 & & $\begin{array}{l}\text { Software } \\
\text { Improvements }\end{array}$ & $\begin{array}{l}\text { M. S. } \\
\text { Harrington }\end{array}$ & $\begin{array}{l}\text { Maintenance } \\
\text { Programs } \\
\text { Integration }\end{array}$ \\
\hline & 6.2 .2 .2 & & $\begin{array}{l}\text { Hardware } \\
\text { Improvements }\end{array}$ & & \\
\hline
\end{tabular}




\begin{tabular}{|c|c|}
\hline 2.A.2 Description of Activities & $\begin{array}{l}\text { Westinghouse Hanford Company } \\
\text { Work Management Administration } \\
\text { SMS/WBS No. } 6.2\end{array}$ \\
\hline Activity & Description \\
\hline $\begin{array}{l}6.2 .1 .1 \\
\text { Work Management Performance } \\
\text { Improvements/Implementation }\end{array}$ & $\begin{array}{l}\text { Hork Management Performance Improvements/Implementation coordinates } \\
\text { work control process improvements for Westinghouse Hanford Company } \\
\text { and subcontractors. Maintenance Programs Integration, the } \\
\text { Hest inghouse group responsible for this activity, serves as the } \\
\text { interpretive authority for maintenance direction received from the } \\
\text { DOE and other sources. Process improvements are directed at making } \\
\text { work management easier to do, track, and report. This activity } \\
\text { also funds finding a commercial replacement for the JCS. }\end{array}$ \\
\hline $\begin{array}{l}6.2 .1 .2 \\
\text { Work Management Documentation }\end{array}$ & $\begin{array}{l}\text { Work Management Documentation ensures that the work management } \\
\text { process incorporates DOE direction and is applied consistently } \\
\text { within the Westinghouse Hanford Company and its subcontractors. } \\
\text { This activity also coordinates external maintenance reporting for } \\
\text { Westinghouse Hanford Company, i.e., Site Maintenance Plan, FY } 97 \\
\text { Infrastructure and Maintenance budget request, Maintenance and } \\
\text { Implementation Plans, and includes funding for planning FY } 96 \\
\text { activities. }\end{array}$ \\
\hline $\begin{array}{l}6.2 .1 .3 \\
\text { Work Management Training }\end{array}$ & $\begin{array}{l}\text { This activity monitors WHC work control-related training and funds } \\
\text { external contracts with specialized instructors for work management } \\
\text { and the JCS. It also funds Davis-Bacon Act Awareness training } \\
\text { performed by program personnel. }\end{array}$ \\
\hline $\begin{array}{l}6.2 .2 .1 \\
\text { Job Control System Network } \\
\text { Maintenance and Operations }\end{array}$ & $\begin{array}{l}\text { Job control system is the computer software designed to help } \\
\text { management organize and monitor work performed by Westinghouse } \\
\text { Hanford Company and subcontractors. This activity includes } \\
\text { monitoring the JCS network performance, troubleshooting and repair } \\
\text { of any network problems, conversion of old computer system data for } \\
\text { JCS use, project management and customer interfaces, and } \\
\text { BCS Richland, Inc. support to replace job control system. }\end{array}$ \\
\hline
\end{tabular}




\begin{tabular}{|l|l|l|}
\hline 2.A.2 Description of Activities & $\begin{array}{l}\text { Westinghouse Hanford Company } \\
\text { Work Management Administration } \\
\text { SMS/WBS No. 6.2 }\end{array}$ & \multicolumn{1}{|c|}{$\begin{array}{c}\text { FY 1995 } \\
\text { Site Support Program Plan } \\
\text { Date Prepared: } 8 / 15 / 94\end{array}$} \\
\hline \multicolumn{1}{|c|}{ Activity } & \multicolumn{1}{|c|}{ Description } \\
$\begin{array}{l}\text { Job Control System Software } \\
\text { Improvements }\end{array}$ & $\begin{array}{l}\text { This activity includes funding and controlling the JCS program } \\
\text { upgrades, simplifying the use of the JCS, and implement ing changes } \\
\text { to bring the JCS into full compliance with the DOE Maintenance } \\
\text { Order, DOE 4330.4B. }\end{array}$ \\
\hline $\begin{array}{l}\text { 6.2.2.3 } \\
\text { Job Control System Hardware } \\
\text { Improvements }\end{array}$ & \begin{tabular}{l} 
This activity funds hardware upgrades to the JCS network. \\
\hline
\end{tabular}
\end{tabular}


Figure 2-1. Work Breakdown Structure (6.2--Work Management Administration).

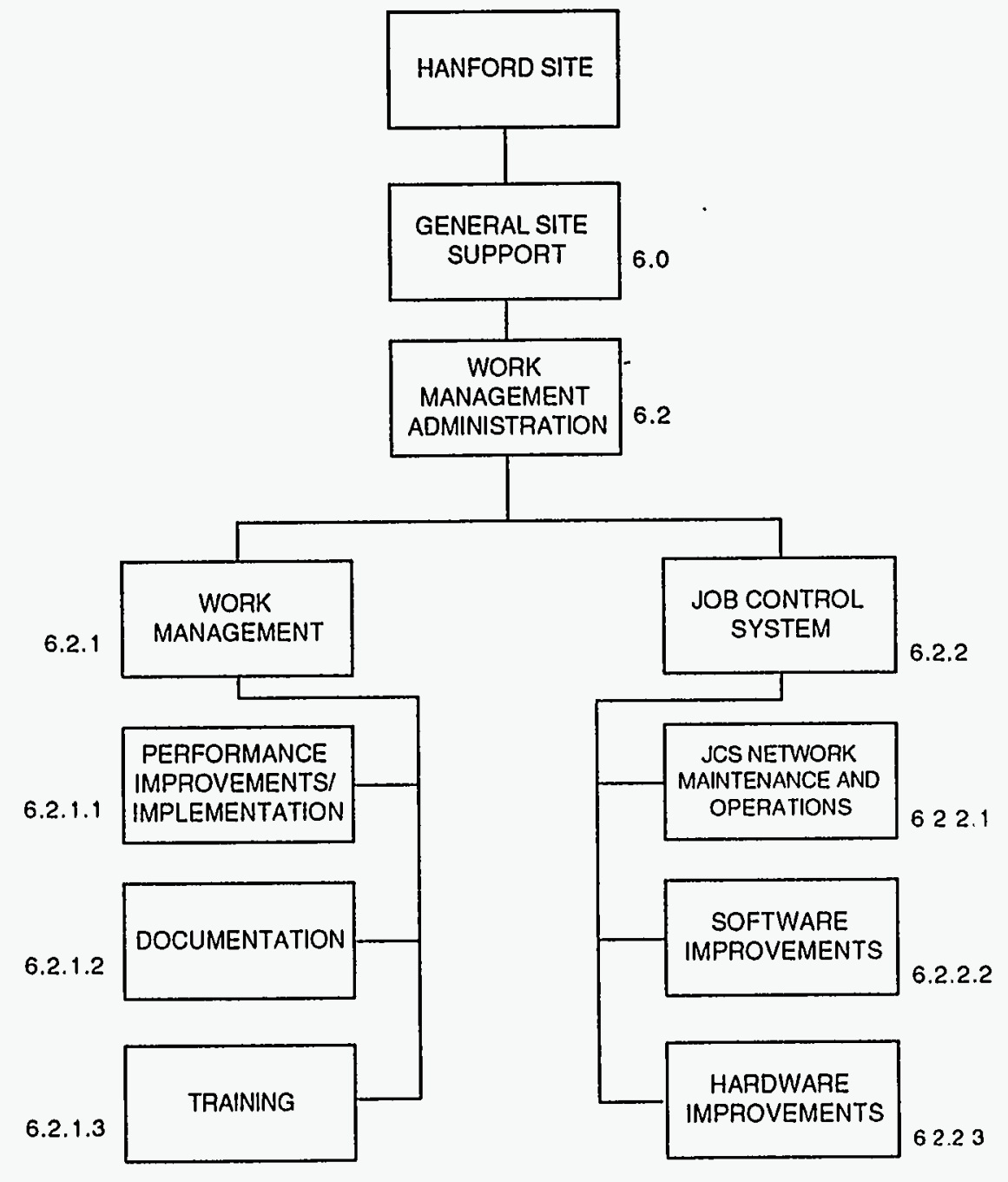




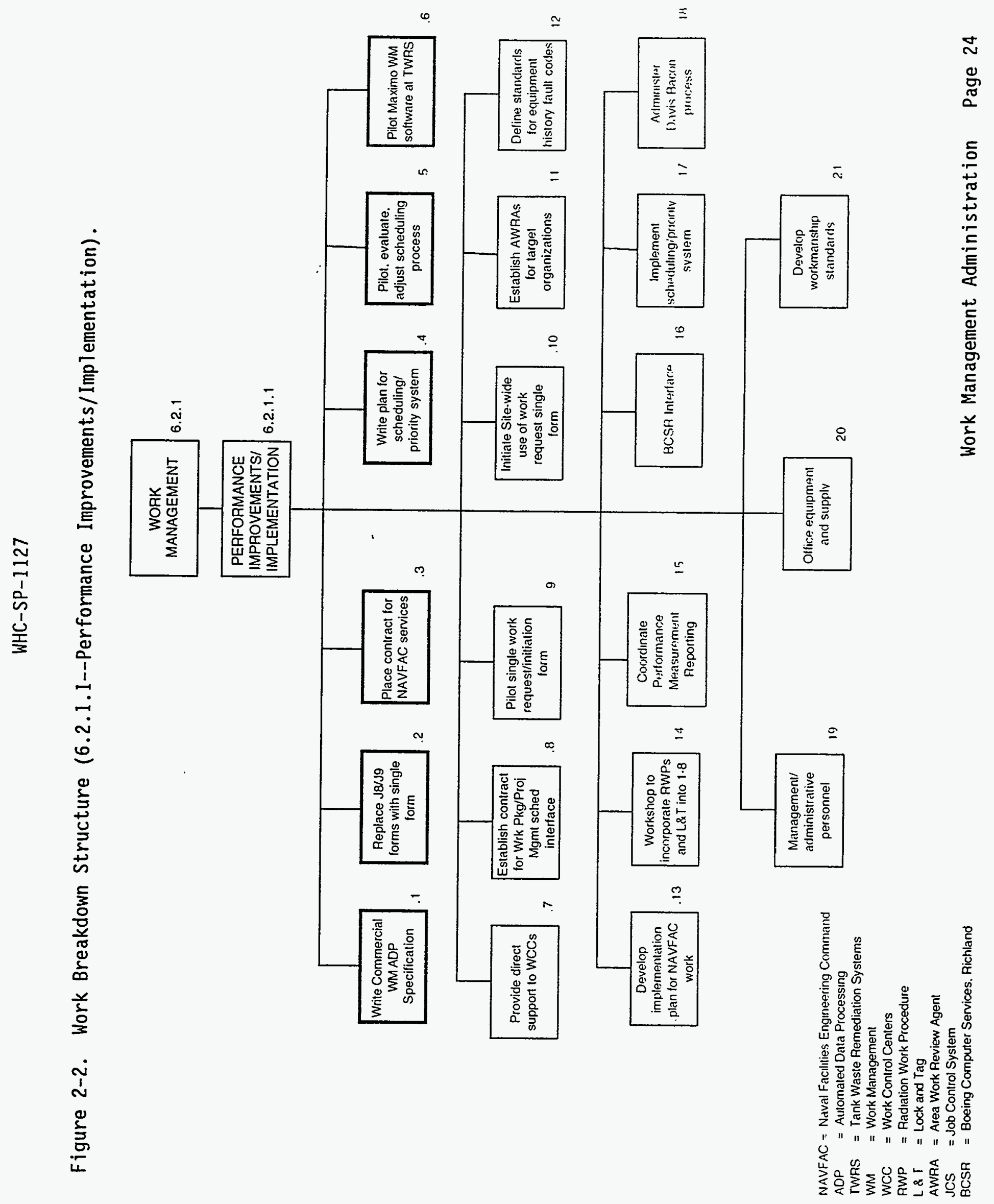


Figure 2-3. Work Breakdown Structure (6.2.1.2--Documentation).

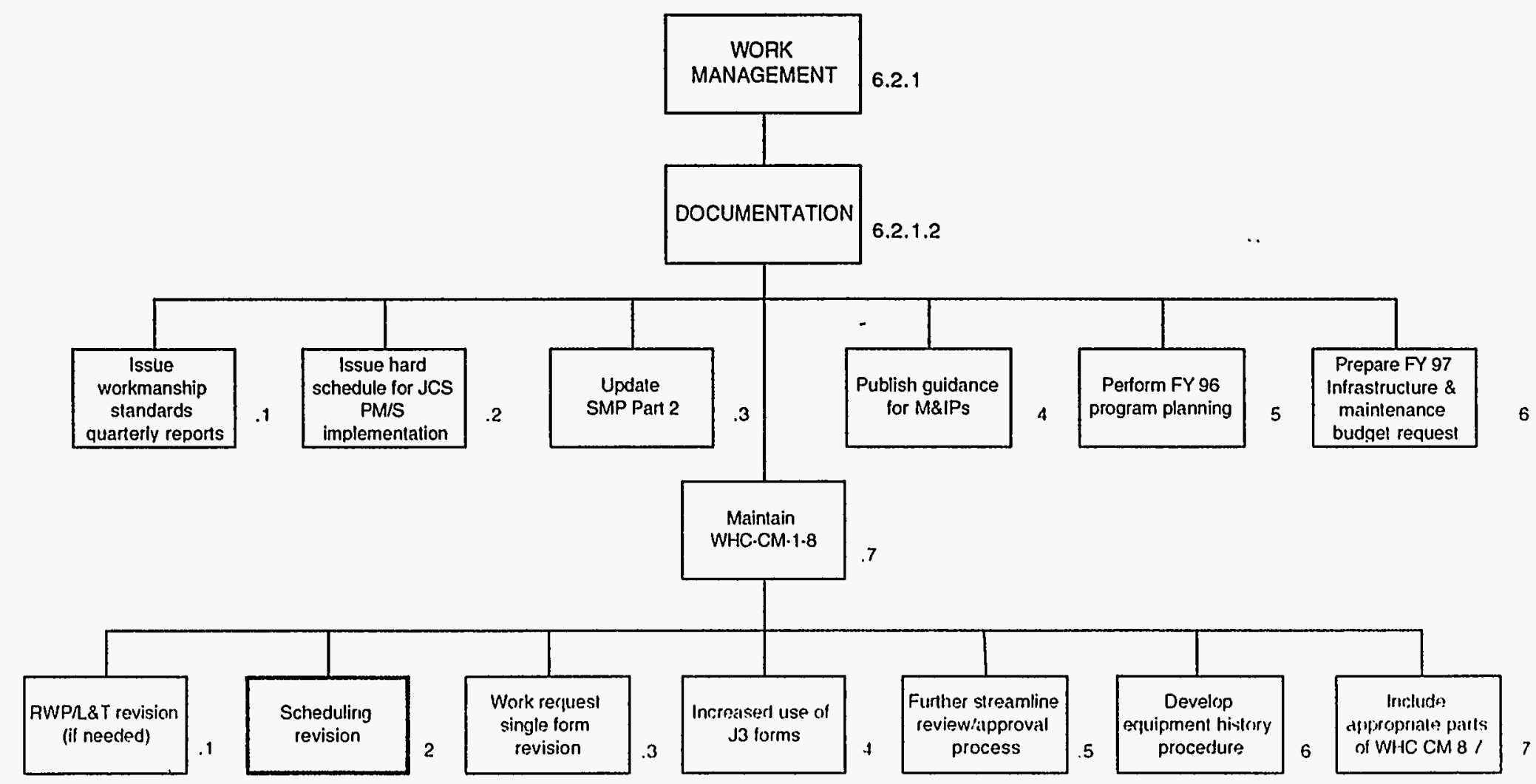

JCS $=$ Job Control System

PM/S = Prevenlive Mainlenance/Surveillance

SMP = Site Maintenance Plan

M\&IP = Maintenance and Implementation Plan

$F Y=$ Fiscal Year

RWP $=$ Radiation Work Permit

L\&T = Lock and Tag 


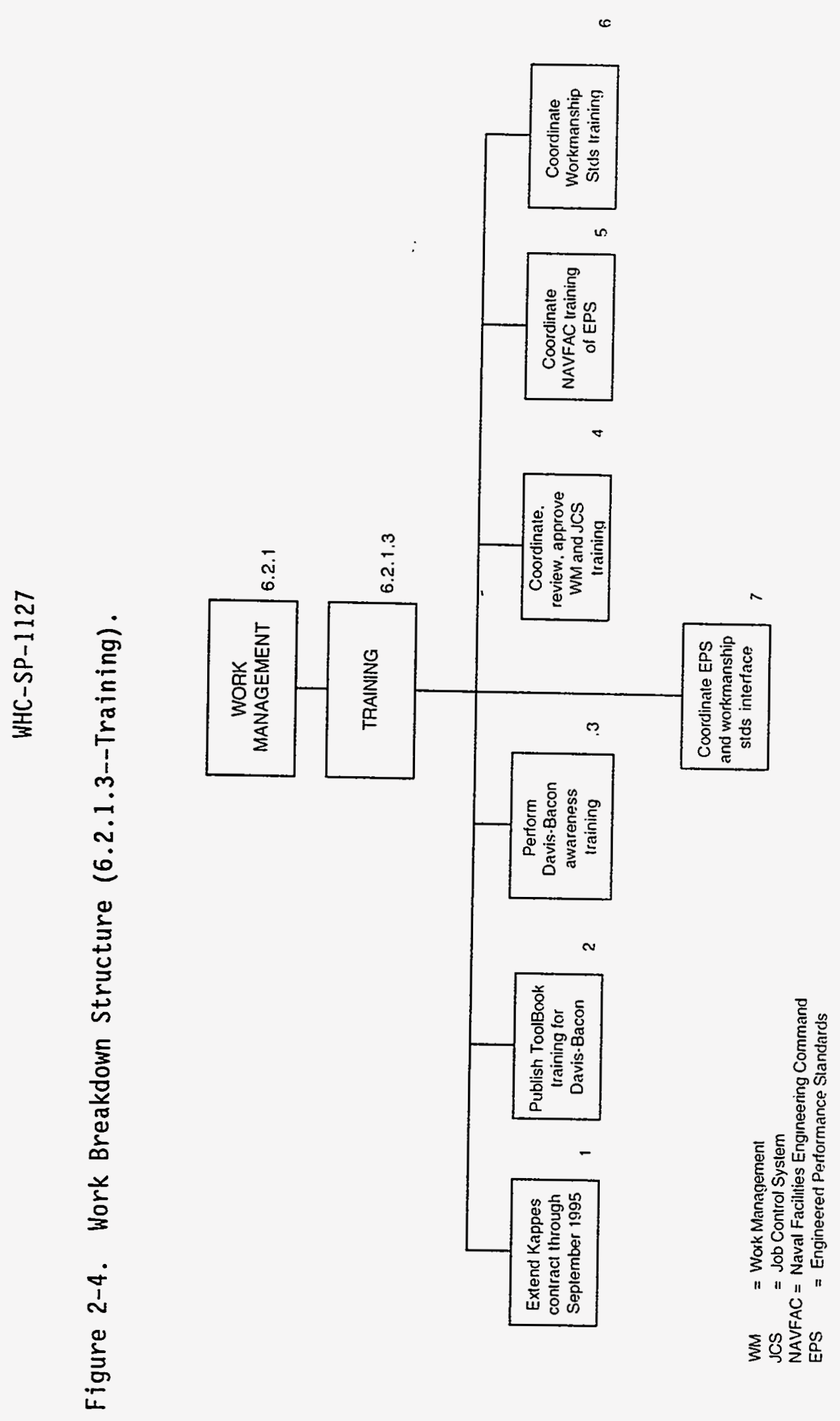

$\stackrel{2}{\sim}$

产

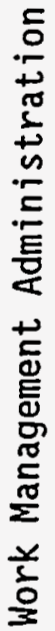


WHC-SP-1127

Figure 2-5. Work Breakdown Structure (6.2.2---Job Control System).

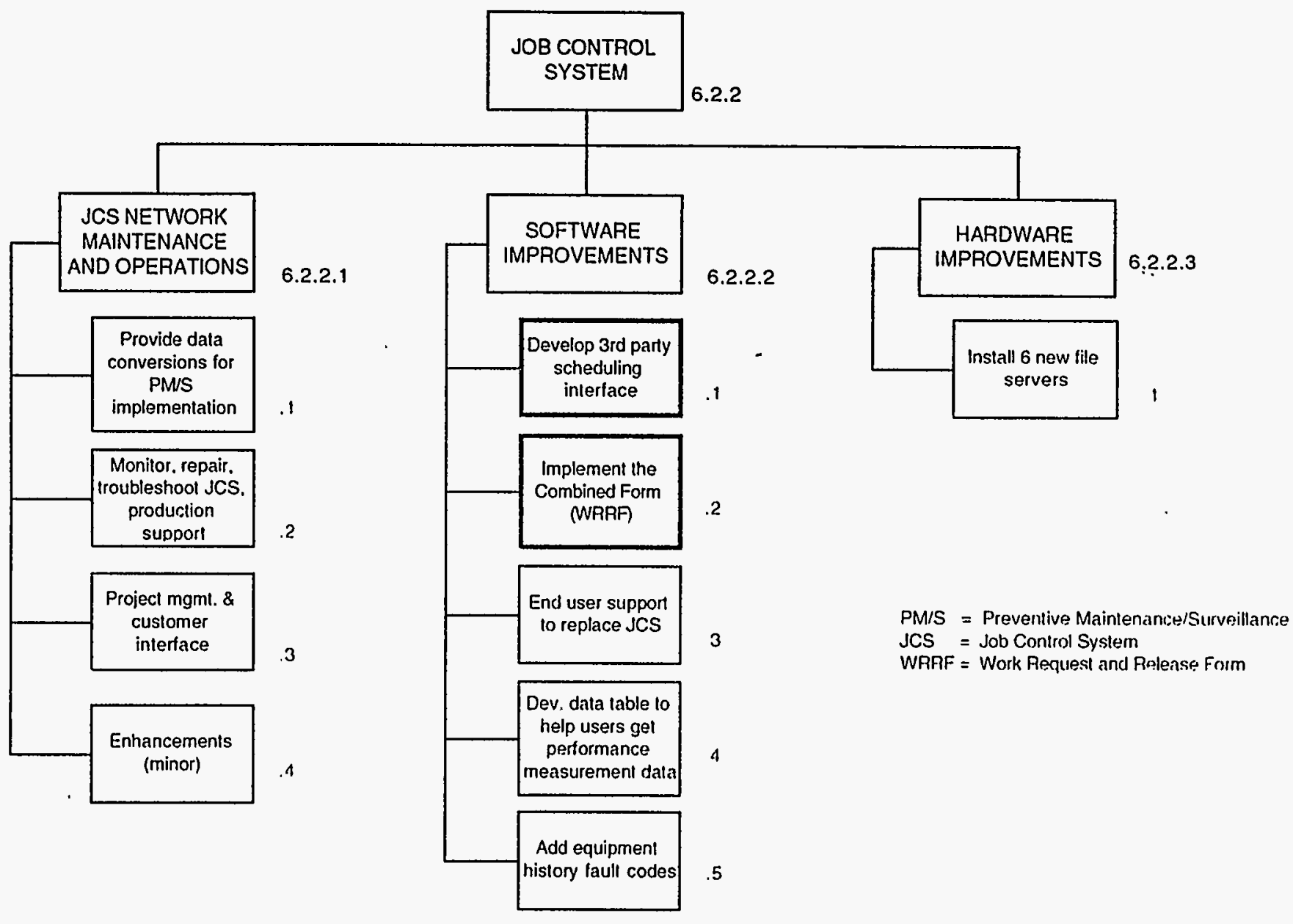




\begin{tabular}{|c|c|c|c|c|}
\hline \multicolumn{3}{|c|}{ 2.B.1 Milestone List } & $\begin{array}{l}\text { Westinghouse Hanford Company } \\
\text { Work Management Administration } \\
\text { SMS/WBS No. } 6.2\end{array}$ & $\begin{array}{l}\text { FY } 1995 \\
\text { Site Support Program Plan } \\
\text { Date Prepared: } 8 / 15 / 94\end{array}$ \\
\hline \multicolumn{2}{|c|}{ Milestone } & \multirow{2}{*}{$\begin{array}{l}\text { WBS } \\
\text { Number }\end{array}$} & \multirow{2}{*}{ Milestone description } & \multirow{2}{*}{ Due date } \\
\hline Type & Number & & & \\
\hline CNTR & WMA-95-001 & 6.2 .1 .1 .1 & $\begin{array}{l}\text { Write the specification requirement for the Site } \\
\text { commercial work management computer program to } \\
\text { replace the job control system software. }\end{array}$ & $10 / 31 / 94$ \\
\hline CNTR & WMA-95-002 & 6.2 .1 .1 .2 & $\begin{array}{l}\text { Replace the } \mathrm{J} 8 / \mathrm{J} 9 \text { forms with a single work release } \\
\text { form. }\end{array}$ & $6 / 30 / 95$ \\
\hline CNTR & WMA-95-003 & 6.2 .1 .1 .3 & Place a contract for NAVFAC services. & $11 / 30 / 94$ \\
\hline CNTR & WMA-95-004 & 6.2 .1 .1 .4 & $\begin{array}{l}\text { Write a plan for implementing a scheduling/priority } \\
\text { system into work management. }\end{array}$ & $2 / 28 / 94$ \\
\hline CNTR & WMA-95-005 & 6.2 .1 .1 .5 & $\begin{array}{l}\text { Pilot, evaluate, and adjust the scheduling/priority } \\
\text { system. }\end{array}$ & $6 / 1 / 95$ \\
\hline CNTR & WMA-95-006 & 6.2 .1 .1 .6 & $\begin{array}{l}\text { Complete a pilot in TWRS of the Maximo work } \\
\text { management software from Project Software and } \\
\text { Development, Inc. }\end{array}$ & $6 / 30 / 95$ \\
\hline CNTR & WMA-95-007 & 6.2 .1 .2 .7 .2 & $\begin{array}{l}\text { Revise WHC-CM-1-8, Work Management, to include the } \\
\text { schedul ing/priority system. }\end{array}$ & $9 / 30 / 95$ \\
\hline CNTR & WMA-95-008 & 6.2 .2 .2 .1 & $\begin{array}{l}\text { Develop third party scheduling interface for the } \\
\text { job control system software. }\end{array}$ & $12 / 31 / 94$ \\
\hline CNTR & WMA-95-009 & 6.2 .2 .2 .2 & $\begin{array}{l}\text { Implement the combined form (WRRF), including fault } \\
\text { codes for equipment history. }\end{array}$ & $6 / 30 / 95$ \\
\hline
\end{tabular}




\begin{tabular}{|c|c|c|}
\hline $\begin{array}{l}\text { 2.C.1 Cost Baseline } \\
\text { by Program Element }\end{array}$ & $\begin{array}{l}\text { Westinghouse Hanford Company } \\
\text { Work Management Administration } \\
\text { SMS/WBS No. } 6.2\end{array}$ & $\begin{array}{c}\text { FY } 1995 \text { SSPP } \\
\text { Date Prepared: } \\
8 / 15 / 94\end{array}$ \\
\hline
\end{tabular}

\begin{tabular}{|l|l|c|}
\hline \multicolumn{1}{|c|}{ FY 1994 Cost Baseline (Dollars in Thousands) } \\
\hline WBS \# & \multicolumn{1}{|c|}{ Title } & Total \$s \\
\hline 6.2 .1 & Work Management & $1,026.3$ \\
\hline 6.2 .2 & Job Control System & $1,484.7$ \\
\hline & & \\
\hline & & \\
\hline & [Excludes company adders (G\&A and CSP/Oversight)] FY 1994 Total for (SMS/WBS No) & $2,511.0$ \\
\hline
\end{tabular}

\begin{tabular}{|l|l|r|}
\hline \multicolumn{1}{|c|}{ FY 1995 Cost Baseline (Dollars in Thousands) } & \\
\hline 6.2 .1 & Work Management & $1,777.3$ \\
\hline 6.2 .2 & Job Control System & 614.0 \\
\hline & & \\
\hline & & \\
\hline & & $2,391.3$ \\
\hline
\end{tabular}




\begin{tabular}{|c|c|c|}
\hline $\begin{array}{l}\text { 2.C. } 1 \text { Cost Baseline } \\
\text { by Program Element }\end{array}$ & $\begin{array}{l}\text { Westinghouse Hanford Company } \\
\text { Work Management Administration } \\
\text { SMS/WBS No. } 6.2\end{array}$ & $\begin{array}{c}\text { FY } 1995 \text { SSPP } \\
\text { Date Prepared: } \\
8 / 15 / 94\end{array}$ \\
\hline
\end{tabular}

\begin{tabular}{|l|l|c|}
\hline \multicolumn{3}{|c|}{ FY 1996 Cost Baseline (Dollars in Thousands) } \\
\hline WBS \# & \multicolumn{1}{|c|}{ Title } & Total \$s \\
\hline 6.2 .1 & Work Management & 850 \\
\hline 6.2 .2 & Job Control System & 452 \\
\hline & & \\
\hline & [Excludes company adders (G\&A and CSP/Oversight)] FY 1996 Total for (SHS/WBS No) & 1,302 \\
\hline
\end{tabular}

\begin{tabular}{|c|c|c|}
\hline \multicolumn{2}{|r|}{ FY 1997 Cost Baseline (Dollars in Thousands) } & \\
\hline 6.2 .1 & Work Management (Davis-Bacon Compliance only) & 187 \\
\hline 6.2 .2 & Other & 280 \\
\hline & & \\
\hline & & \\
\hline & & \\
\hline & [Excludes company adders (G\&A and CSP/Oversight)] FY 1997 Total for (SMS/WBS No) & 467 \\
\hline
\end{tabular}




\begin{tabular}{|l|c|c|}
\hline 2.C.2 Cost Basis & $\begin{array}{c}\text { Westinghouse Hanford Company } \\
\text { Work Management Administration } \\
\text { SMS/WBS No. } 6.2\end{array}$ & $\begin{array}{c}\text { FY } 1995 \\
\text { Site Support Program P1 an } \\
\text { Date Prepared: } 8 / 15 / 94\end{array}$ \\
\hline
\end{tabular}

\subsubsection{Hork Management}

The operating costs for FY 1995 work activities are estimated based on FY 1994 services provided in support of WHC senior management strategic initiatives and RL's expectations to improve Sitewide work control practices. The FY 1995 cost estimates for this element's activities are based on resources and materials required to accomplish the milestones, and deliverables negotiated with RL for FY 1995 . This level of support is expected to decrease in FY 1996 parallel with declining transitioning project plant missions, and projected outsourcing of various Site maintenance support activities. This work element should be fully implemented, and is projected to be completed by the end of FY 1996.

\subsubsection{Job Control System}

The costs basis for FY 1995 work activities for this work element are based on historical data for services provided in FY 1993 and FY 1994. The cost of this work element decreases during FY 1995 showing a reduction in labor and associated materials, with incremental decrease through FY 1996 and FY 1997. This decrease is congruent with completion of work scope, declining plant missions, and a focus to improve cost effectiveness of operations through pursuit of commercial software that will replace the JCS. 


\section{C.3 FTES}

Westinghouse Hanford Company Work Management Administration SMS/WBS No. 6.2
FY 1995

Site Support Program Plan

Date Prepared: 8/15/94

\begin{tabular}{|c|c|c|c|c|c|c|c|c|}
\hline \multicolumn{9}{|c|}{ WBS $6.2 .1 .1 \quad$ (IMDKOAOA) } \\
\hline \multicolumn{4}{|c|}{ Ful1-Time Equivalent Staff by Job Description } & \multicolumn{5}{|c|}{ NOTE: Job Family Oniy After 1996} \\
\hline JOB FAMILYY & & $\therefore$ & & $\therefore$ & $\ldots$ & 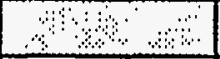 & $\therefore$ & $\therefore$ \\
\hline Job category & 1994 & 1995 & 1996 & 1997 & 1998 & 1999 & 2000 & 2001 \\
\hline MANAGERS & & & & 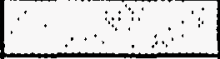 & 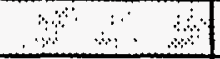 & : & $\therefore$ & $\therefore$ \\
\hline First line & 1.00 & 0.82 & 1.00 & 0.0 & & & & \\
\hline ENGINEERS & ' & $\therefore$ & & 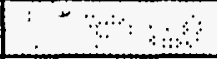 & : & $\therefore$ & & \\
\hline other & & 8.30 & 4.00 & 2.00 & & & & \\
\hline GEN ADM/SECRETARY/CLERK & & $\because$ & & $\because \quad 3$ & 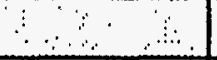 & $\cdots: \because$ & $\because$ & \\
\hline Secretaries & & 0.97 & 1.00 & 0.0 & & & & \\
\hline
\end{tabular}

\begin{tabular}{|c|c|c|c|c|c|c|c|c|}
\hline \multicolumn{9}{|c|}{ WBS 6.2 .1 .2 (1MDKOAOB) } \\
\hline \multicolumn{4}{|c|}{ Ful1-Time Equivalent Staff by Job Description } & \multicolumn{5}{|c|}{ NOTE: Job Family Only After 1996} \\
\hline JOB FAMILY & $\therefore$ & a & $\cdot \cdot$ & की & 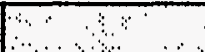 & Q & $\because$ & $\therefore$ \\
\hline Job category & 1994 & 1995 & 1996 & 1997 & 1998 & 1999 & 2000 & 2001 \\
\hline$\therefore \quad \therefore \quad \therefore \quad \cdots$ & $\because \ldots . .$. & $\therefore: \therefore$ & $\because$ & $\cdots$ & \% & \% & 8 & \\
\hline First line & 0 & 0.15 & 0 & 0.0 & & & & \\
\hline ENGINEERS & & $\ldots \ldots$ & : & $\therefore \because \quad \Leftrightarrow$ & & \% & $\therefore \therefore$ & $\because$ \\
\hline other & 19.0 & 1.46 & 3.00 & 0 & & & & \\
\hline
\end{tabular}




\begin{tabular}{|c|c|c|c|c|c|c|c|c|}
\hline \multicolumn{9}{|c|}{ WBS 6.2.1.3 (IMDKOAOC) } \\
\hline \multicolumn{4}{|c|}{ Full-Time Equivalent Staff by Job Description } & \multicolumn{5}{|c|}{ NOTE: Job Family Only After 1996} \\
\hline Jos fantllo & ४২\%॰ & ४ষ : & ও४४ & ২ং০ঃ৪। & ২. ঋ. & ४। & ४२\% & ms: \\
\hline Job category & 1994 & \begin{tabular}{|l|}
1995 \\
\end{tabular} & 1996 & 1997 & 1998 & 1999 & 2000 & 2001 \\
\hline MANAGERS & ४०.: & $\therefore: \vdots:$ & @ै। & \%ै। & ৪ঃঃঃ। & 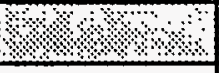 & ४०.: & +2: \\
\hline First line & & 0.03 & 0.0 & 0.0 & & & & \\
\hline ENGINEERS & :४ & : & थलि & ४४०: & ख़। & ४ै২। : & १ै०े & in \\
\hline other & & 1.94 & 1.0 & 0.0 & & & & \\
\hline GEN ADM/SECRETARY/CLERKK & 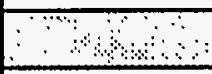 & $8 \times 2$ & \& & $4 \cdots$ & १ै००० & s: & क्ष: & +: \\
\hline Secretaries & & 0.03 & 0.0 & 0.0 & & & & \\
\hline
\end{tabular}




\begin{tabular}{|c|c|c|c|c|c|c|c|c|}
\hline \multicolumn{9}{|c|}{ WBS 6.2.2.1 (1MOKOAOD) } \\
\hline \multicolumn{4}{|c|}{ Full-Time Equivalent Staff by Job Description } & \multicolumn{5}{|c|}{ NOTE: Job Family Only After 1996} \\
\hline JOB FAMILY & \% & 8 & $\therefore$ & $\therefore$ & $\therefore-3$ & 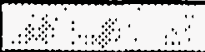 & $\therefore \quad$ & $\therefore$ \\
\hline Job category & 1994 & 1995 & 1996 & 1997 & 1998 & 1999 & 2000 & 2001 \\
\hline MANAGERS: : & $\therefore \quad \therefore$ & $\therefore$ & . & $\therefore$ & . & २? & $\therefore$ & $\because \because$ \\
\hline First line & & 0.75 & 1.0 & 1.0 & & & & \\
\hline ENGINEERS & & & $\therefore$ & . & $\%$ & ? & . & $\because$ \\
\hline Computer & & 3.75 & 3.0 & 2.0 & & & & \\
\hline
\end{tabular}

\begin{tabular}{|c|c|c|c|c|c|c|c|c|}
\hline \multicolumn{9}{|c|}{ WBS 6.2 .2 .2 (1MDKOAOE) } \\
\hline \multicolumn{4}{|c|}{ Ful1-Time Equivalent Staff by Job Description } & \multicolumn{5}{|c|}{ NOTE: Job Family Only After 1996} \\
\hline JOB FAMILY & & & $\therefore$ & $\therefore$ & $\because$ & $\therefore$ & & \\
\hline Job category & 1994 & 1995 & 1996 & 1997 & 1998 & 1999 & 2000 & 2001 \\
\hline \multicolumn{9}{|l|}{ ENGINEERS } \\
\hline Computer & & 2.4375 & 1.0 & 0.0 & & & & \\
\hline
\end{tabular}

\begin{tabular}{|c|c|c|c|c|c|c|c|c|}
\hline \multicolumn{9}{|c|}{ WBS 6.2 .2 .3 (1MDKOAOF) } \\
\hline \multicolumn{4}{|c|}{ Ful1-Time Equivalent Staff by Job Description } & \multicolumn{5}{|c|}{ NOTE: Job Family Only After 1996} \\
\hline JOB FAMILY & & & $\therefore$ & $\therefore$ & & $\therefore \cdots$ & & \\
\hline Job category & 1994 & 1995 & 1996 & 1997 & 1998 & 1999 & 2000 & 2001 \\
\hline ENGINEERS & .. & & & & & & & \\
\hline Computer & & 0.0625 & 0.0 & 0.0 & & & & \\
\hline
\end{tabular}




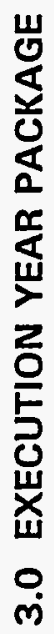




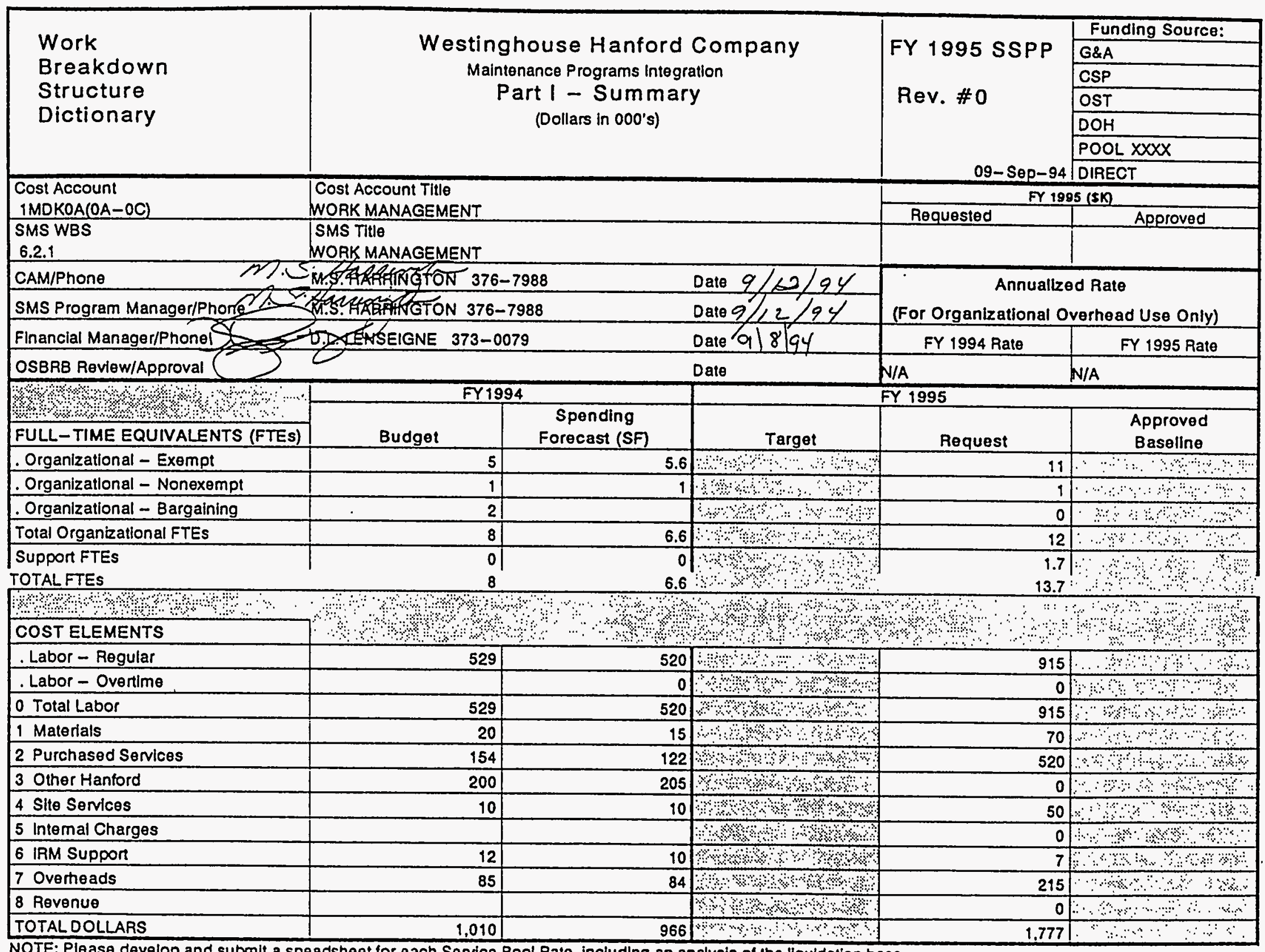

NOTE: Please develop and submil a speadsheet for each Service Pool Rate, including an analysis of the liquidation base.
o.trmptorm 
WHC-SP-1127

\begin{tabular}{|l|c|c|}
\hline $\begin{array}{l}\text { Work Breakdown } \\
\text { Structure } \\
\text { Dictionary }\end{array}$ & Westinghouse Hanford Company & Faintenance Program Integration \\
Part II - Element Definition & REV. \#0 \\
\hline
\end{tabular}

\begin{tabular}{|c|c|c|}
\hline \multirow[t]{2}{*}{$\begin{array}{l}\text { WORK BREAKDOWN STRUCTURE DICTIONARY } \\
\text { PART II - ELEMENT DEFINITION } \\
\text { INDEX LINE NO. }\end{array}$} & \multicolumn{2}{|c|}{$\begin{array}{l}\text { WBS ELEMENT CODE: } 6.2 .1 \\
\text { TITLE: WORK MANAGEMENT } \\
\text { CONTRACTOR: WHC }\end{array}$} \\
\hline & REVISION NO. AND AUTHORIZATION & DATE \\
\hline \multicolumn{3}{|l|}{ APPROVED CHANGES } \\
\hline $\begin{array}{l}\text { SYSTEM DESIGN DESCAIPTION } \\
\text { NUMBER: } \\
\text { TITLE: }\end{array}$ & \multicolumn{2}{|l|}{ FUNDING DOCUMENTS } \\
\hline \multicolumn{3}{|c|}{$\begin{array}{l}\text { ELEMENT TASK DESCAIPTION } \\
\text { COST CONTENT - } \\
\text { The Work Management element operates using the Westinghouse Hantord Company and ICF-KH self liquldating pool concept. This budget source funds } \\
\text { technical engineering support lo maintenance Integration activities required to support silte Work Management, consulting and mentoring services, } \\
\text { administration of Davis - Bacon and administration costs for Work Management. }\end{array}$} \\
\hline \multicolumn{3}{|c|}{$\begin{array}{l}\text { TECHNICAL CONTENT - } \\
\text { The Work Management element to the WHC Maintenance Administration Program provides technical and administrative support to the operatlon of several } \\
\text { sltewlde maintenance processes. Work Management supports WHC stiewide Implementattion and compllance with DOE } 4330.48 \text {, Maintenance Management } \\
\text { Program. Work Management element supports coordination and development of the Site Maintenance Plan, development and coordinatlon of sitewide } \\
\text { maintenance performance measurements, Annual Cross - Cut Budget Submittal, and the sitewide WHC Maintenance Program Pollcy and Procedure Manuals. } \\
\text { The Work Management element provides and coordinates consulting and mentoring services, in support of RL, to aid in the site Work Management processes. } \\
\text { The Work Management element also reviews and approves all Work Management and JCS ADP training developed by Technical Training for end users. }\end{array}$} \\
\hline \multicolumn{3}{|l|}{$\frac{\text { OBJECTNES - }}{\text { Se日 attached pages. }}$} \\
\hline \multicolumn{3}{|l|}{$\frac{\text { ASSUMPTIONS/CONSTRAINTS - }}{\text { SeO attached pages. }}$} \\
\hline
\end{tabular}


Part II - Element Definition (continued)

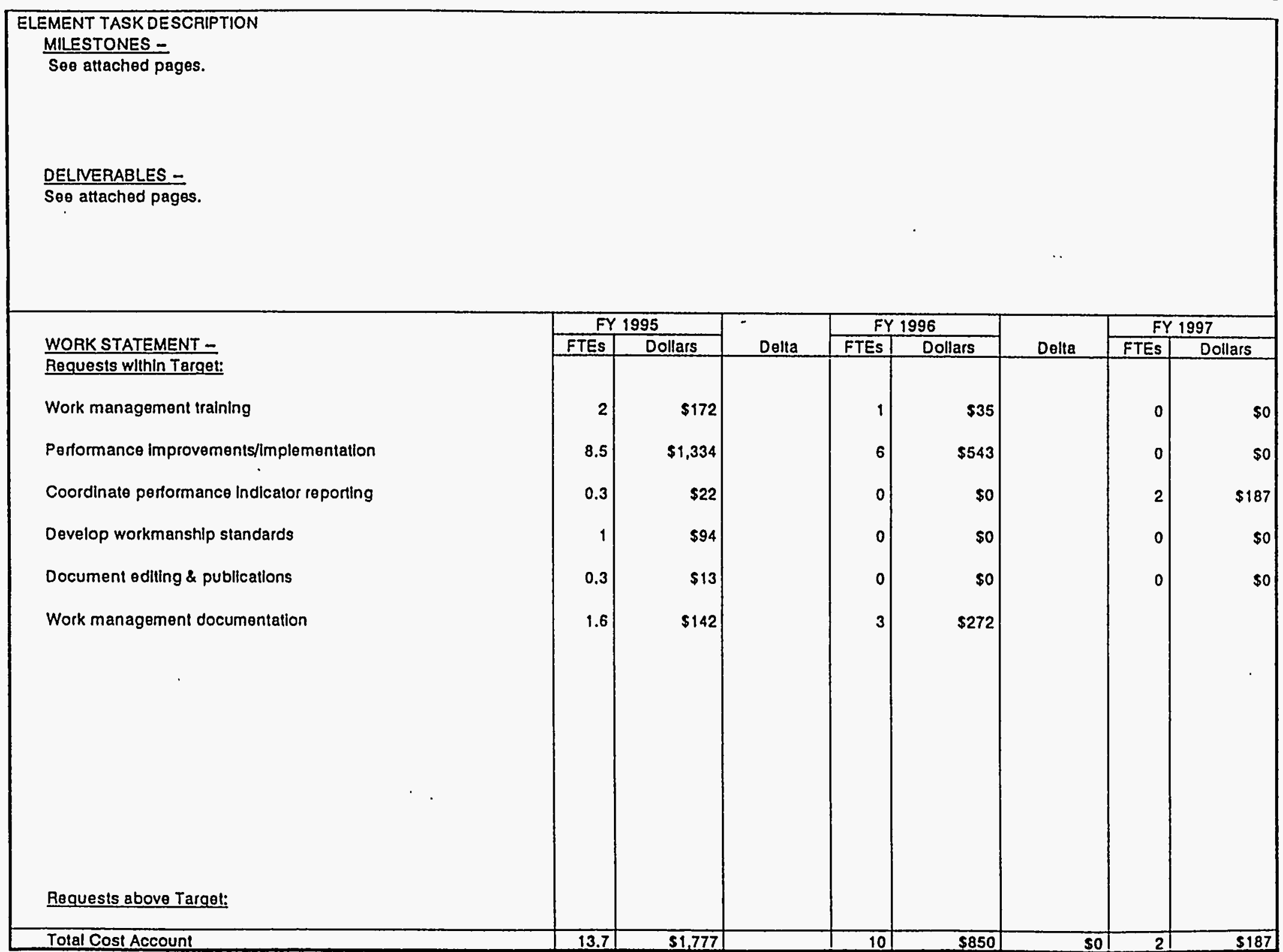




\section{ADDENDUH TO WORK BREAKDOWN STRUCTURE DICTIONARY}

\section{FOR WBS 6.2.1, WORK MANAGEMENT}

\section{OBJECTIVES}

Objective 1

Define process and measurements needed to implement work management.

Goa7s:

1) Take leadership role in establishing EPS

- Develop an implementation plan for adopting NAVFAC EPS

- Tailor EPS to individual plants

- Integrate EPS with workmanship standards

- Integrate EPS factors into training

2) Take leadership role in establishing workmanship standards

- Pilot - issue workmanship standards

- Establish consistent site training of workmanship standards with the Technical Training organization

- Coordinate training for using workmanship standards with the Technical Training organization

3) Establish work scheduling guidance that fulfills program objectives and publish in WHC-CM-1-8 Site-wide manual

- Establish an integrated priority system meaningful to Site operations in support of work management Site objectives

- Run a pilot program in THRS

4) Establish guidance for developing uniform plant M\&IPs for nuclear facilities

- Publish guidance for the M\&IPs, with plant involvement

- Incorporate guidance for using SELs and MELs

5) Incorporate SEL and MEL guidance into WHC-CM-1-8, Work Management

6) Re-evaluate Site work management performance measures in terms of equipment availability

7) Update Part 2 of the Site Maintenance Plan for 1995 maintenance activities

8) Define standards for equipment history (fault codes for equipment failure). Publish standards in WHC-CM-1-8, Hork Management.

\section{Objective 2}

Define the training needed to communicate the work management process. 
WHC-SP-1127

Goals:

1) Extend the Kappes Consulting contract through June 1995 for continued work management training and mentoring. As a minimum, mentoring in field will focus on support to the plants in the following areas:

- Suggested supervisor time in the field

- Establishing optimum performance objectives

- Pre-release process delays

- Post-release suspension rate

- Adherence to the schedule

2) Ensure the basic scheduler training need is met by reviewing Project Software and Development, Inc. scheduler training results. Extend, modify or replace based on results.

3) Continue administration of Davis Bacon compliance activities. Provide additional assistance in the following areas:

- Provide Davis-Bacon training

- Make the computer-based training course (in ToolBook) available to the Site on Davis-Bacon file server

- Write the desk instruction for preparing plant forces work reviews

- Add new examples of plant forces work reviews to those already available on the Davis-Bacon file server

- Expand the Area Work Review Agent (AWRA) base to include Radio Maintenance, Security Maintenance, Boeing Computer Services Maintenance, Telecommunications, Projects and Facilities Management. (This includes getting AWRA's assigned and providing the required training.)

4) Continue review input and support of the work management training, coordinated with the Technical Training organization

5) Coordinate development and review/approve all JCS training provided by the Technical Training organization

\section{Objective 3}

Provide mentoring work management for work control centers.

Goals:

1) Provide personnel to advise facility personnel on work management issues associated with the process, associated data processing or procedures manual.

2) Provide assistance to field personnel to optimize work package processes

3) Communicate lessons learned and good practices observed to facilitate most effective work management practices.

\section{Objective 4}

Document the work management process. 


\section{Objective 5}

Provide resolution to plant specific and Sitewide work management issues raised in FY 1995.

\section{Objective 6}

Continue coordinating plant implementation of the JCS preventive maintenance/surveillance and equipment history modules in accordance with established schedule.

\section{Objective 7}

Evaluate the need and make recommendations to replace the JCS software program with a commercial work management program.

\section{Goals:}

1) Establish the minimum operating criteria for a work management computer program to meet Site needs.

2) Review open market work management products to obtain the most cost effective computer software system to meet the established criteria.

3) Pilot and implement the selected software package.

\section{Objective 8}

Continue to streamline work initiation and release processes to support smoother transition to commercial software application selected to replace the existing JCS.

\section{ASSUMPTIONS/CONSTRAINTS}

1) The Site Procedures group will maintain responsibility for interfacing with user groups relative to statutory permits.

2) Completion/closure of work packages is the responsibility of the facility owners/managers.

3) Work management will continue to improve at a pace that will allow this program to dissolve by FY 1997.

4) Customer support for implementing EPS will continue throughout the implementation effort.

5) Naval Facilities Engineering Command personnel will. be available to support implementation of EPS.

6) We can use a high percentage of the material developed by NAVFAC for ICF KH.

7) There will be continued support and funding for developing workmanship standards. 
8) There will be continued matrix support from Procedures Development, Tank Waste Remediation Services, Technical Training and the Crafts organizations.

9) Reorganizations will trigger a revision to the Site Maintenance Plan, Part 1.

10) There will be adequate support to drive development of a planning and scheduling manual.

11) There will be a sponsor to pilot a planning and scheduling system to be included in a manual.

12) The Work Management Sub-Council will sponsor FY 1996 implementation of a planning and scheduling manual.

13) There will be adequate contract support to assist with development of a planning and scheduling manual.

14) There will be elements of the old WHC-CM-8-8 manual that will need to be included in the WHC-CM-1-8 manual.

15) Kappes Consulting will be available to support work management implementation through June 1995.

16) Groups targeted to assign Area Work Review Agents will support their assignment.

17) There will be continued customer support for a single work form to initiate and conduct work to aid in streamlining the work management process.

18) The MAXIMO program, produced by PSDI, will adequately replace the JCS and be compatible with the network.

19) The MAXIMO program can be readily obtained for a Tank Waste Remediation Systems pilot program.

20) There will be continued support to adopt single work release form methodology.

Any item on the list of assumptions could conceivably become an issue and constrain the program. The Work Management Administration Program has the potential to be constrained by change in senior management objectives or lack of funding due to decreases in congressional support for the Hanford Site.

\section{ELEMENT TASK DESCRIPTION}

\section{Milestones}

- Develop a work management ADP specification document for commercial software in support of pursuing replacement of current JCS software by $10 / 31 / 94$.

- Replace J8/J9 forms with a single form by $6 / 30 / 95$. 
- P1ace contract for NAVFAC Services by $11 / 30 / 94$.

- Develop a plan for scheduling/priority system installation by $2 / 28 / 95$.

- Pilot, evaluate, and adjust scheduling process by $6 / 1 / 95$.

- Revise HHC-CM-1-8 to incorporate results of scheduling pilot by $9 / 30 / 95$.

- Pilot Maximo commercial work management software in TWRS by $6 / 30 / 95$.

Deliverables

- Issue firm implementation schedule for completing the JCS PM/S module by $12 / 31 / 94$.

- Pilot single work request/initiation form by $12 / 31 / 94$.

- Develop a Site training program by $12 / 31 / 94$.

- Revise WHC-CM-1-8 to include changes in draft by $12 / 31 / 94$.

- Implement the use of form and issue manual change by $4 / 31 / 95$.

- Put Tool Book on Davis-Bacon file server by 10/31/94.

- Provide Davis Bacon awareness training to Radio Maintenance, Security Maintenance, BCSR Maintenance, Telecommunications, Projects, Facility Management and Procurement personnel by 9/31/95.

- Establish Area Work Review Agents for these organizations by 9/31/95.

- Update Site Maintenance Plan Part 2 by $4 / 15 / 95$.

- Define standards for equipment history fault codes by $1 / 31 / 95$.

- Develop an implementation plan for NAVFAC work by $11 / 30 / 94$.

- Issue workmanship standards update and coordinate training on a quarterly schedule.

- Create Site guidance for developing consistent maintenance and implementation plans (incorporate importance of SEL/MEL) by 10/31/94.

- Conduct workshop to investigate the feasibility of incorporating RWP and Lock and Tag into the WHC-CM-1-8 procedure by 6/31/95.

- Extend the Kappes Consulting contract (for continued mentoring support to end users) by 10/31/94. 


\begin{tabular}{|c|c|c|c|c|c|}
\hline \multirow{6}{*}{$\begin{array}{l}\text { Work } \\
\text { Breakdown } \\
\text { Structure } \\
\text { Dictionary }\end{array}$} & \multirow{6}{*}{\multicolumn{3}{|c|}{$\begin{array}{l}\text { Westinghouse Hanford Company } \\
\text { Maintenance Programs Integration } \\
\text { Part I - Summary } \\
\text { (Dollars in 000's) }\end{array}$}} & \multirow{6}{*}{$\begin{array}{r}\text { FY } 1995 \text { SSPP } \\
\text { Rev. \#0 } \\
\text { 09-Sep-94 }\end{array}$} & \multirow{3}{*}{\begin{tabular}{|l|} 
Funding Source: \\
G\&A \\
CSP \\
\end{tabular}} \\
\hline & & & & & \\
\hline & & & & & \\
\hline & & & & & OST \\
\hline & & & & & DOH \\
\hline & & & & & \begin{tabular}{|l} 
POOL XXX \\
ORECT
\end{tabular} \\
\hline Cost Account & Cost Account Title & & & $\begin{aligned} \text { FY } 1905 \\
\end{aligned}$ & $25(5 n)$ \\
\hline IMDKOA $(O D-O F)$ & JOB CONTROL SYSTEM & & & Requested & Approved \\
\hline $\begin{array}{l}\text { SMS WBS } \\
6.2 .2\end{array}$ & $\begin{array}{l}\text { SMS Title } \\
\text { JOB GONTROL SYSTEM }\end{array}$ & & & & \\
\hline CAM/Phone $\quad n=1$ & M. A hakping Ton 376 & 7988 & Date: $9 / 12 / 94$ & Annuallze & d Rate \\
\hline SMS Program Manager/Phonêl:-S. & 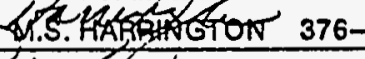 & & Date: $9 / 12 / 94$ & (For Organizational Ov & verhead Use Only) \\
\hline Financial Manager/Phone 1 & D.L. UENSEIGNE 373-00 & & Date: 918194 & FY 1994 Rate & FY 1995 Rate \\
\hline OSBRB Review/Approval & & & Date & N/A & N/A \\
\hline 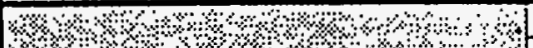 & FY199 & & & FY 1995 & \\
\hline $\begin{array}{l}\text { স } \\
\text { FULL-TIME EQUIVALENTS (FTES) }\end{array}$ & Budget & $\begin{array}{c}\text { Spending } \\
\text { Forecast (SF) }\end{array}$ & Target & Request & $\begin{array}{c}\text { Approved } \\
\text { Baseline }\end{array}$ \\
\hline Organizational - Exempi & 2 & 2 & मি४\%: & 0 & 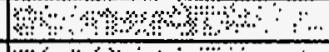 \\
\hline . Organizational - Nonexempi & & & \% $3 \times 3$ & 요 & $10 \% 3 \%$ \\
\hline Organlzational - Bargaining & & & अ12\%, & 0 & m. \\
\hline Total Organizational FTEs & 2 & 2 & म०० & 0 & मिए, \\
\hline Support FTES & 10 & 10.5 & अ४४४। & 7.2 & 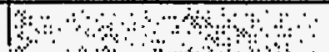 \\
\hline TOTAL FTES & 12 & 12.5 & \% & 7.2 & 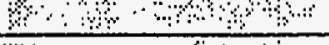 \\
\hline & & & & & ২্য আ আ \\
\hline COST ELEMENTS & & & & & \\
\hline . Labor - Regular & 806 & 761 & म००४४४ & 501 & 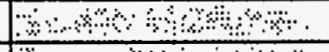 \\
\hline Labor - Oventime & 0 & 4 & - & 0 & :ness \\
\hline 0 Total Labor & 806 & 765 & \%, & 0 & 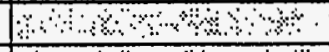 \\
\hline 1 Materials & 109 & 151 & $\mathrm{~W}$ & 0 & $1 \times 3$ \\
\hline 2 Purchased Senvices & 150 & 70 & $2 \%<>+\%$ & 0 & \% \\
\hline 3 Other Hantord & 5 & 20 & 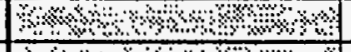 & 0 & W \\
\hline 4 Site Senvices & 0 & 41 & $3 \% \times \% 3$ & 0 & 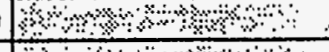 \\
\hline 5 Intemal Charges & 0 & 9 & $1 \times 4 \times$ & 0 & $1 \times+0 \times 4$ \\
\hline 6 IRM Suppont & 0 & 46 & $13 \mathrm{O}+1$ & 0 & $13 \times+4 \times$ \\
\hline 7 Overheads & 431 & 394 & $3,3,8 \times 8 \times \times \times$ & 193 & $40 \times 3 \% 3 \%$ \\
\hline 8 Revenue & & 0 & $14 \times 8 \times 1801$ & 0 & 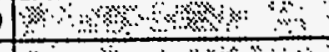 \\
\hline TOTALDOLLARS & 1,501 & 1.496 & 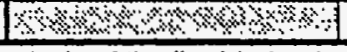 & 614 & 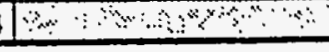 \\
\hline
\end{tabular}

NOTE: Please develop and submil a speadsheet for each Service Pool Rale, including an andysis of the liquidation base. o.truptorm 
WHC-SP-1127

\begin{tabular}{|l|c|c|}
\hline $\begin{array}{l}\text { Work Breakdown } \\
\text { Structure }\end{array}$ & Westinghouse Hanford Company \\
Dictionary & Maintenance Programs Integration & FY 1995 SSPP \\
REV. \#0 & Rart II - Element Definition \\
\hline
\end{tabular}

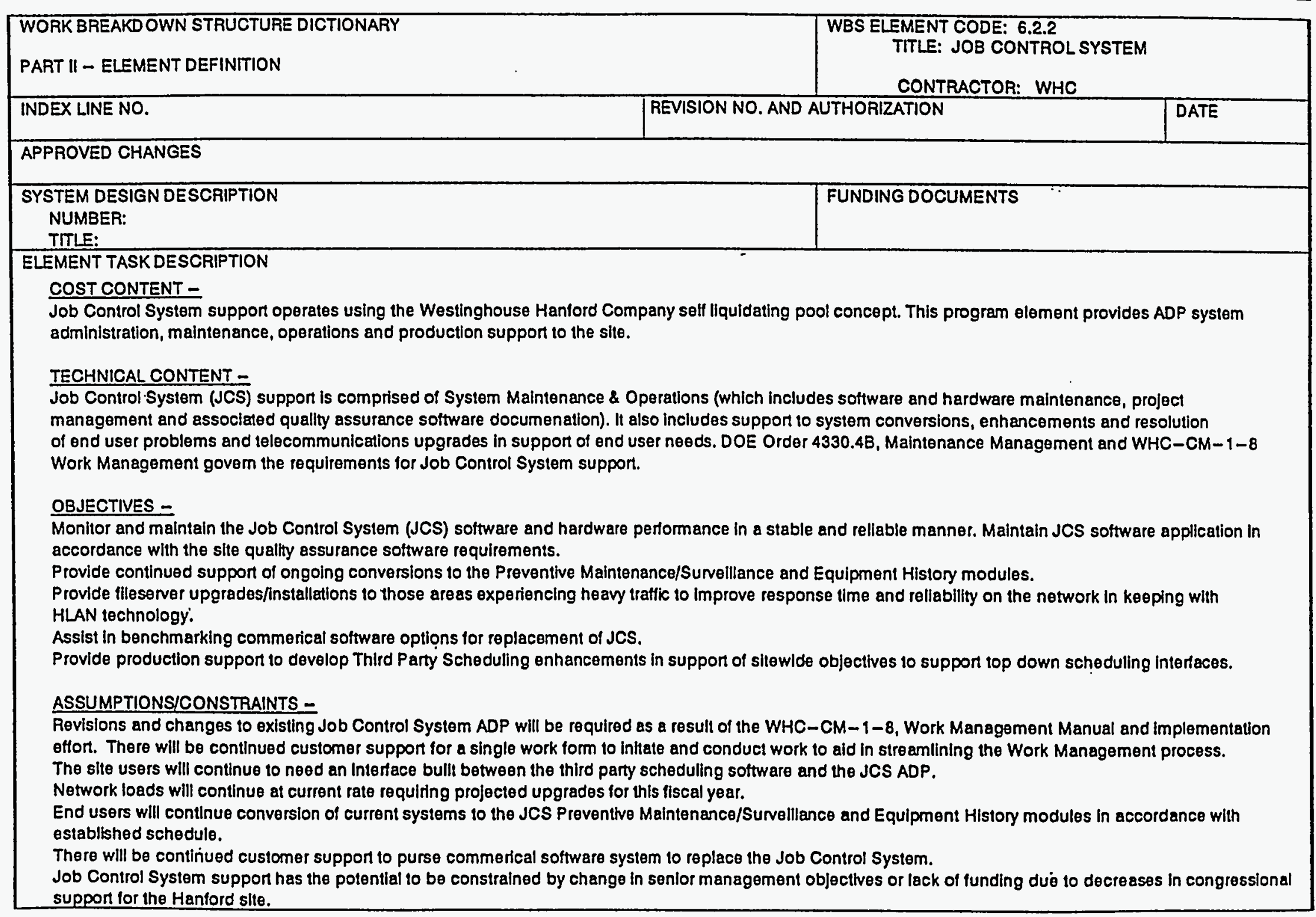




\section{Part II - Element Definition (continued)}

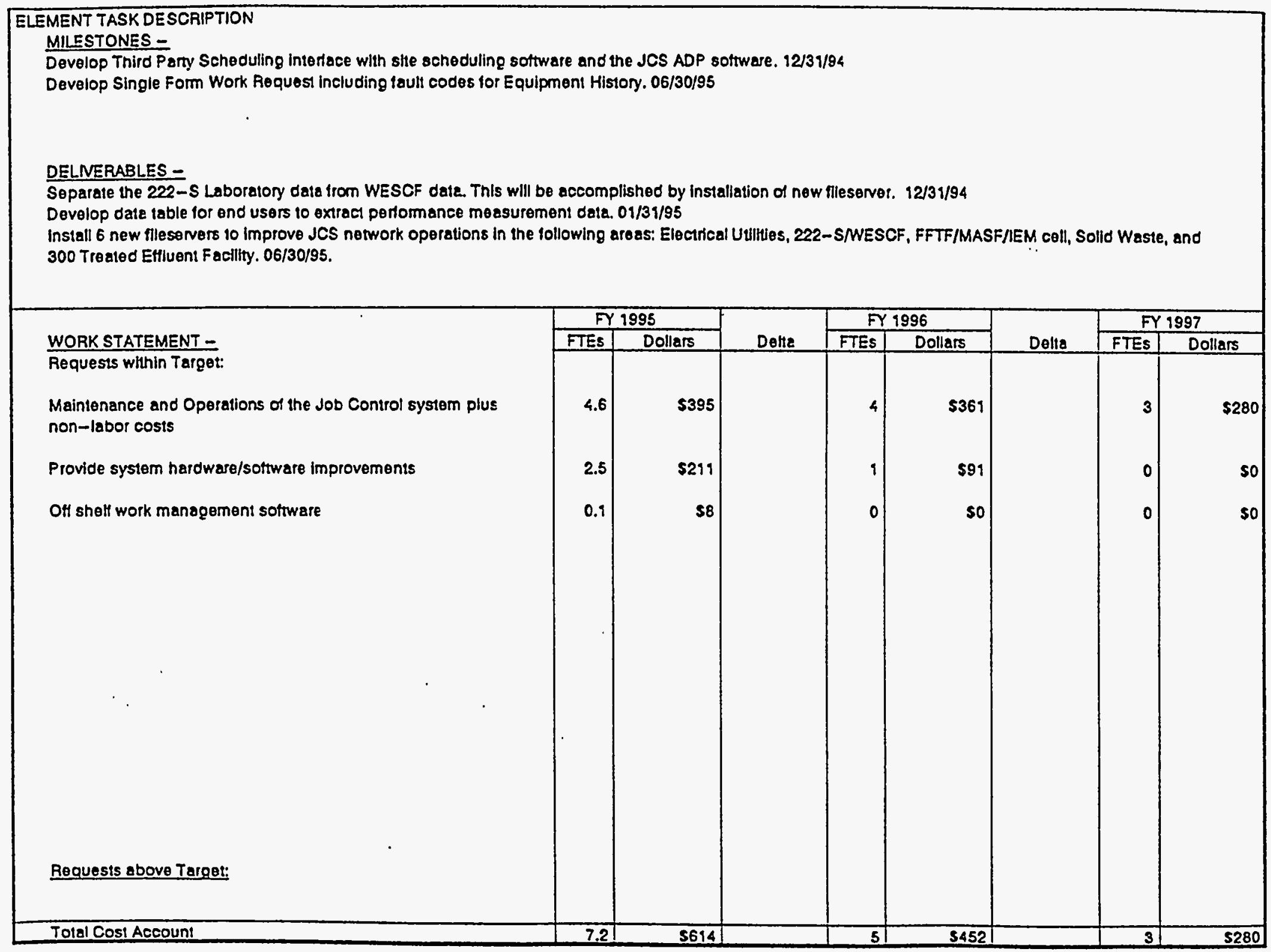




\begin{tabular}{|c|c|c|c|}
\hline $\begin{array}{l}\text { Title: Write jo } \\
\text { specification do }\end{array}$ & $\begin{array}{l}\text { ontrol syst } \\
\text { lent }\end{array}$ & :ement software & $\begin{array}{l}\text { Date Prepared: } \\
8 / 15 / 94\end{array}$ \\
\hline Assigned To: $M$. & - Harrington & & CIN: \\
\hline WBS Designator: & 6.2 .1 .1 .1 & & $\begin{array}{l}\text { Due Date: } \\
10 / 31 / 94\end{array}$ \\
\hline Control Number: & MA-95-001 & & Revision: 0 \\
\hline $\begin{array}{l}\text { Milestone Type: } \\
\square \text { DOE-HQ } \\
\square \text { DOE-RL } \\
\text { CNTR }\end{array}$ & $\begin{array}{l}\text { Division: } \\
\square \text { State } \\
\square \text { Federal } \\
\text { DOE } \\
\square \text { RCRA } \\
\square \text { TPA\# }\end{array}$ & $\begin{array}{l}\text { Deliverable: } \\
\square \text { Report } \\
\square \text { Letter } \\
\square \text { Drawings } \\
\text { Other } \\
\text { (specify) } \\
\text { Software } \\
\text { Specification } \\
\text { Document }\end{array}$ & $\begin{array}{l}\text { Address to: } \\
\square \text { DOE-HQ } \\
\text { DOE-RL } \\
\square \text { Other } \\
\text { (specify) }\end{array}$ \\
\hline Milestone Descri & & & \\
\hline $\begin{array}{l}\text { To replace the } j \\
\text { package, softwar } \\
\text { specifications } d \\
\text { candidate work } \mathrm{m}\end{array}$ & $\begin{array}{l}\text { control sys } \\
\text { package spec } \\
\text { ument. Thes } \\
\text { agement soft }\end{array}$ & $\begin{array}{l}\text { ware with a comm } \\
\text { ons need to be fo } \\
\text { ications are the } \\
1 \text { be measured ag }\end{array}$ & $\begin{array}{l}\text { al software } \\
\text { ly stated in a } \\
\text { indards that } \\
\text { t. }\end{array}$ \\
\hline Description of $w$ & constitute & tion of this mi & \\
\hline $\begin{array}{l}\text { This milestone } \\
\text { for work managem }\end{array}$ & $\begin{array}{l}\text { be complet } \\
\text { software } i\end{array}$ & $\begin{array}{l}\text { the software sp } \\
n \text { and internall }\end{array}$ & 0 \\
\hline $\begin{array}{l}\text { Cost Account Man } \\
\text { pl. S. Hanes }\end{array}$ & $\underline{a}, \quad 9$ & $\begin{array}{c}\text { Program/Project } \\
n / .5 \text { S Aace }\end{array}$ & ager \\
\hline $\begin{array}{l}\text { Program Element } \\
\text { B. S. /tane }\end{array}$ & $\stackrel{\text { ager }}{\longrightarrow}, 9$ & DOE Monitor & \\
\hline
\end{tabular}


Title: Replace the $38 / J 9$ forms with a single work release form.

\begin{tabular}{|l|l}
\hline Assigned To: M. S. Harrington \\
\hline WBS Designator: & 6.2 .1 .1 .2 \\
\hline Control Number: & WMA-95-002 \\
\hline Milestone Type: & Division: \\
$\begin{array}{l}\text { DOE-HQ } \\
\text { DOE-RL }\end{array}$ & $\square$ State \\
$\begin{array}{l}\text { CNTR } \\
\end{array}$ & $\square$ DOderal \\
& $\square$ RCRA \\
& $\square$ TPA\# \\
\hline
\end{tabular}

(2)

Deliverable:

$\square$ Report

Letter

Drawings

other

(specify)

Revision of

HHC-CM-1-8
Date Prepared:

$8 / 15 / 94$

CIN:

Due Date: $6 / 30 / 95$

Revision: 0

Address to:

$\square$ DOE-HQ

DOE-RL

Other

(specify)

\section{Milestone Description}

This milestone will simplify the work release process by combining two forms.

\section{Description of what constitutes completion of this milestone:}

This milestone will be completed with a published revision of the WHC-CM-1-8 Work Management manual that incorporates a single work release form.

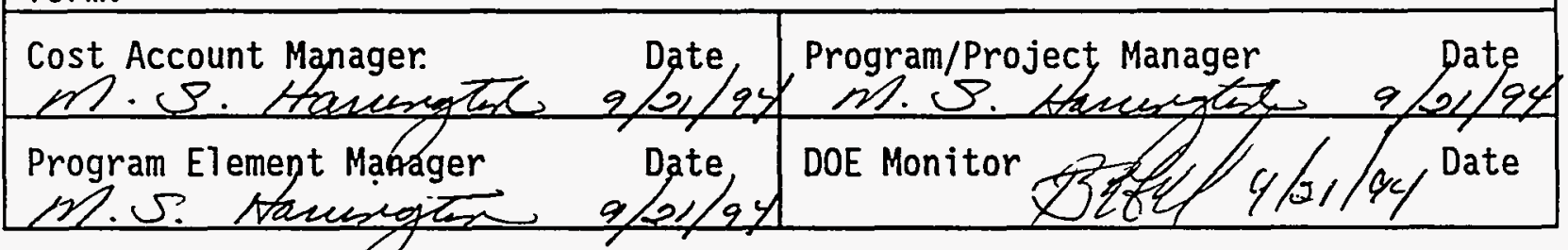




\begin{tabular}{|c|c|c|c|}
\hline \multicolumn{3}{|c|}{$\begin{array}{l}\text { Title: } \\
\text { Place contract for NAVFAC services }\end{array}$} & $\begin{array}{l}\text { Date Prepared: } \\
8 / 15 / 94\end{array}$ \\
\hline \multicolumn{3}{|c|}{ Assigned To: M. S. Harrington } & CIN: \\
\hline \multicolumn{3}{|c|}{ WBS Designator: $\quad 6.2 .1 .1 .3$} & $\begin{array}{l}\text { Due Date: } \\
11 / 30 / 94\end{array}$ \\
\hline \multicolumn{3}{|c|}{ Control Number: HMA-95-003 } & Revision: 0 \\
\hline $\begin{array}{l}\text { Milestone Type: } \\
\text { DOE-HQ } \\
\text { DOE-RL } \\
\text { CNTR }\end{array}$ & $\begin{array}{l}\text { Division: } \\
\square \text { State } \\
\square \text { Federal } \\
\text { DOE } \\
\square \text { RCRA } \\
\square \text { TPA\# }\end{array}$ & $\begin{array}{l}\text { Deliverable: } \\
\square \text { Report } \\
\square \text { Letter } \\
\square \text { Drawings } \\
\text { Other } \\
\text { (specify) } \\
\text { Contract with } \\
\text { NAVFAC. }\end{array}$ & $\begin{array}{l}\text { Address to: } \\
\square \text { DOE-HQ } \\
\text { DOE-RL } \\
\text { Other } \\
\text { (specify) }\end{array}$ \\
\hline \multicolumn{4}{|c|}{ Milestone Description } \\
\hline \multicolumn{4}{|c|}{$\begin{array}{l}\text { The Naval Facilities Engineering Command (NAVFAC) has developed engineered } \\
\text { performance standards (EPS) for performing work. Evaluation of NAVFAC EPS } \\
\text { indicates they would be useful for planners to more accurately and } \\
\text { efficiently plan work at Hanford. Rather than re-develop EPS on our own, } \\
\text { we plan to contract with NAVFAC to acquire their EPS. }\end{array}$} \\
\hline \multicolumn{4}{|c|}{ Description of what constitutes completion of this milestone: } \\
\hline \multicolumn{4}{|c|}{$\begin{array}{l}\text { This milestone will be completed with placement of a contract to acquire } \\
\text { NAVFAC EPS, along with NAVFAC expertise in customizing the EPS for Hanford. }\end{array}$} \\
\hline \multicolumn{2}{|c|}{$\begin{array}{l}\text { Cost Account Manager } \\
\text { N.S. Date }\end{array}$} & \multicolumn{2}{|c|}{$\begin{array}{l}\text { Program/Project Manager } \\
\text { M.S. Date }\end{array}$} \\
\hline \multicolumn{2}{|c|}{ 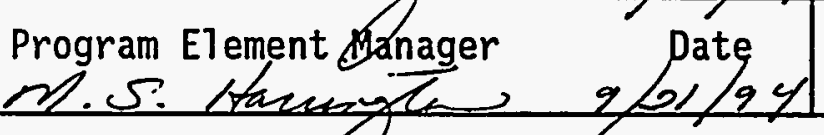 } & \multicolumn{2}{|c|}{ 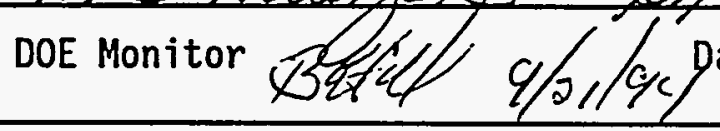 } \\
\hline
\end{tabular}


Title:

Write a plan for implementing a Scheduling/Priority

Date Prepared:

System into Work Management

Assigned To: M. S. Harrington

CIN:

WBS Designator: $\quad 6.2 .1 .1 .4$

Due Date: $2 / 28 / 95$

Control Number: WMA-95-004

Milestone Type:

Division:
$\square \quad$ State
$\square$ Federal
$\square$ DOE
$\square$ RCRA
$\square$ TPA\#

$\square$ DOE-HQ DOE-RL

- CNTR TPA\#

Deliverable:

$\square$ Report

$\square$ Letter

$\square$ Drawings

ather (specify) Implementation Plan Revision: 0

Address to:

$\square$ DOE-HQ

- DOE-RL

Other (specify)

\section{Milestone Description}

There is presently no single guide for scheduling and prioritizing work at Hanford facilities, although there is guidance for projects. This milestone will establish guidance for scheduling and prioritization of work at the facility level.

Description of what constitutes completion of this milestone:

This milestone will be completed with the development of an implementation plan that establishes a single guide for a work management scheduling/ priority system.

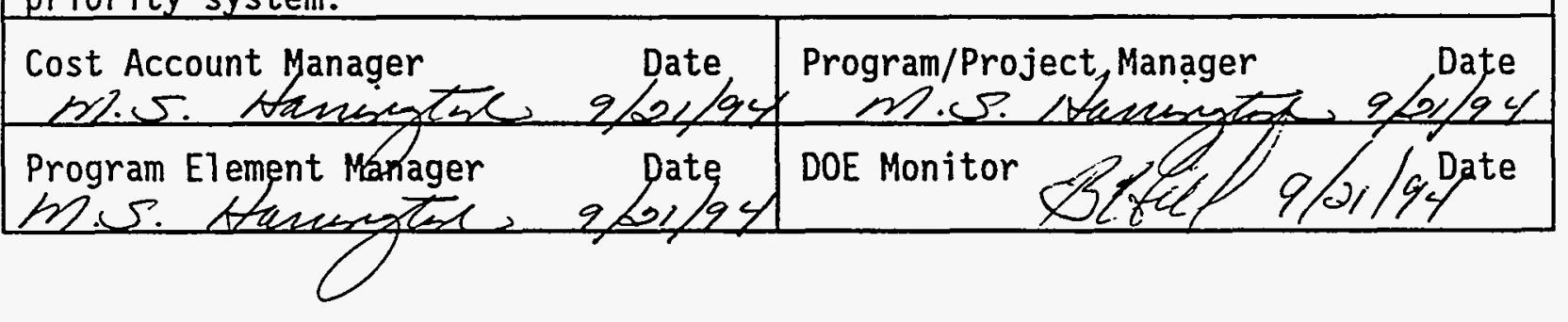


Westinghouse Hanford Company MILESTONE DESCRIPTION SHEET

\begin{tabular}{|c|c|c|}
\hline \multicolumn{2}{|c|}{$\begin{array}{l}\text { Title: } \\
\text { Pilot, evaluate, and adjust the scheduling/priority } \\
\text { system for work management }\end{array}$} & $\begin{array}{l}\text { Date Prepared: } \\
8 / 15 / 94\end{array}$ \\
\hline \multicolumn{2}{|l|}{ Assigned To: M. S. Harrington } & CIN: \\
\hline \multicolumn{2}{|l|}{ WBS Designator: $\quad 6.2 .1 .1 .5$} & $\begin{array}{l}\text { Due Date: } \\
6 / 1 / 95\end{array}$ \\
\hline \multicolumn{2}{|l|}{ Control Number: WMA-95-005 } & Revision: 0 \\
\hline 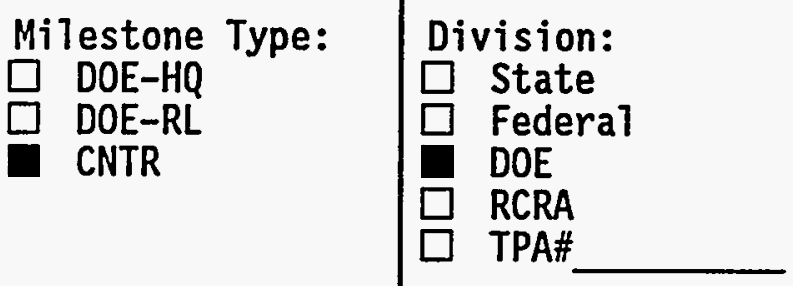 & $\begin{array}{l}\text { Del iverable: } \\
\text { Report } \\
\square \text { Letter } \\
\square \text { Drawings } \\
\square \text { Other } \\
\text { (specify) }\end{array}$ & $\begin{array}{l}\text { Address to: } \\
\begin{array}{|l}\square \\
\text { DOE-HQ } \\
\text { DOE-RL } \\
\text { Other } \\
\text { (specify) }\end{array}\end{array}$ \\
\hline \multicolumn{3}{|l|}{ Milestone Description } \\
\hline \multicolumn{3}{|c|}{$\begin{array}{l}\text { This is a follow-on milestone to milestone WMA-95-004, and is the first } \\
\text { step in implementing a scheduling/priority system for work management. The } \\
\text { pilot program will be used to test the system in a work setting and } \\
\text { identify system improvements needed before Site-wide implementation. }\end{array}$} \\
\hline \multicolumn{3}{|c|}{ Description of what constitutes completion of this milestone: } \\
\hline \multicolumn{3}{|c|}{$\begin{array}{l}\text { This milestone is completed by issuing a lessons learned report at the } \\
\text { conclusion of the scheduling/priority system pilot. }\end{array}$} \\
\hline \multirow{2}{*}{ 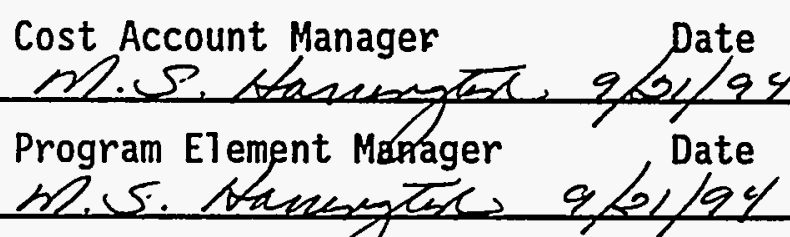 } & \multicolumn{2}{|c|}{ 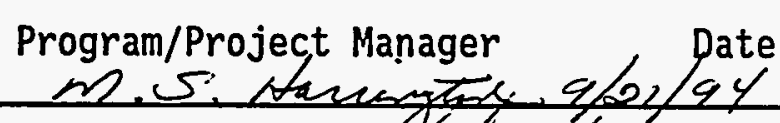 } \\
\hline & DOE Monitor & $q / \delta / i c$ Pate \\
\hline
\end{tabular}




\begin{tabular}{|c|c|c|c|}
\hline \multicolumn{3}{|c|}{$\begin{array}{l}\text { Title: } \\
\text { Complete a THRS pilot of the Maximo software. }\end{array}$} & $\begin{array}{l}\text { Date Prepared: } \\
8 / 15 / 94\end{array}$ \\
\hline \multicolumn{3}{|c|}{ Assigned To: M. S. Harrington } & CIN: \\
\hline \multicolumn{3}{|c|}{ WBS Designator: $\quad$ 6.2.1.1.6 } & $\begin{array}{l}\text { Due Date: } \\
6 / 30 / 95\end{array}$ \\
\hline \multicolumn{3}{|c|}{ Control Number: WMA-95-006 } & Revision: 0 \\
\hline $\begin{array}{l}\text { Milestone Type: } \\
\square \text { DOE-HQ } \\
\square \text { DOE-RL } \\
\text { CNTR }\end{array}$ & $\begin{array}{l}\text { Division: } \\
\square \text { State } \\
\square \text { Federal } \\
\square \text { DOE } \\
\square \text { RCRA } \\
\square \text { TPA\# } \\
\end{array}$ & $\begin{array}{l}\text { Deliverable: } \\
\text { Report } \\
\square \text { Letter } \\
\square \text { Drawings } \\
\square \text { Other } \\
\text { (specify) }\end{array}$ & $\begin{array}{l}\text { Address to: } \\
\square \text { DOE-HQ } \\
\square \text { DOE-RL } \\
\square \text { Other } \\
\text { (specify) }\end{array}$ \\
\hline \multicolumn{4}{|c|}{ Milestone Description } \\
\hline \multicolumn{4}{|c|}{$\begin{array}{l}\text { Preliminary market search for commercially available work management } \\
\text { software indicates a high probability that Maximo. (a product of Project } \\
\text { Software and Development, Inc.) will meet the Site's needs. A pilot of the } \\
\text { Maximo software in TWRS will test that premise. }\end{array}$} \\
\hline \multicolumn{4}{|c|}{ Description of what constitutes completion of this milestone: } \\
\hline \multicolumn{4}{|c|}{$\begin{array}{l}\text { This milestone will be completed with the production of a lessons learned } \\
\text { document from the pilot. The document will also make a recommendation } \\
\text { regarding the Site-wide use of Maximo. }\end{array}$} \\
\hline \multicolumn{2}{|c|}{ 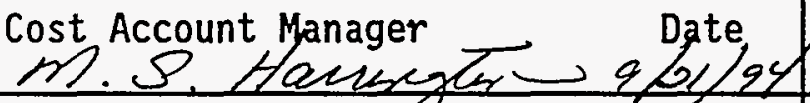 } & \multicolumn{2}{|c|}{ 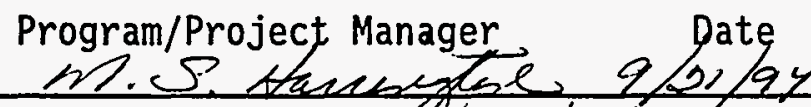 } \\
\hline \multicolumn{2}{|c|}{$\begin{array}{l}\text { Program Element Manager } \\
\text { MJ.S. Date }\end{array}$} & \multicolumn{2}{|c|}{ 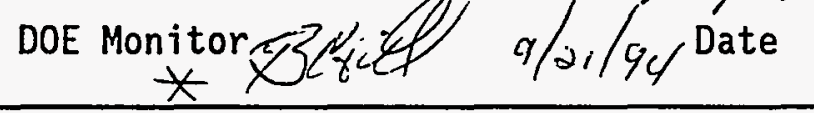 } \\
\hline
\end{tabular}




\section{Westinghouse Hanford Company MILESTONE DESCRIPTION SHEET}

Title: Revise HHC-CM-1-8 to include a Scheduling/Priority System

Date Prepared:

Scheduling/Priority system

Assigned To: M. S. Harrington

$8 / 15 / 94$

\begin{tabular}{|c|c|c|c|}
\hline \multicolumn{3}{|c|}{ Assigned To: M. S. Harrington } & CIN: \\
\hline WBS Designator: & \multicolumn{2}{|l|}{6.2 .1 .2 .7 .2} & $\begin{array}{l}\text { Due Date: } \\
9 / 30 / 95\end{array}$ \\
\hline \multicolumn{3}{|c|}{ Control Number: WMA-95-007 } & Revision: \\
\hline $\begin{array}{l}\text { Milestone Type: } \\
\square \text { DOE-HQ } \\
\square \text { DOE-RL } \\
\text { CNTR }\end{array}$ & $\begin{array}{l}\text { Division: } \\
\square \text { State } \\
\square \text { Federal } \\
\text { DOE } \\
\square \text { RCRA } \\
\square \text { TPA\# }\end{array}$ & $\begin{array}{l}\text { Deliverable: } \\
\square \text { Report } \\
\square \text { Letter } \\
\square \text { Drawings } \\
\text { Other } \\
\text { (specify) } \\
\text { Revision of WHC- } \\
\text { CM-1-8 }\end{array}$ & $\begin{array}{l}\text { Address to: } \\
\square \text { DOE-HQ } \\
\text { DOE-RL } \\
\square \text { Other } \\
\text { (specify) }\end{array}$ \\
\hline \multicolumn{4}{|c|}{ Milestone Description } \\
\hline \multicolumn{4}{|c|}{$\begin{array}{l}\text { This milestone is a follow-on milestone to WMA-95-004 and WMA-95-005. It } \\
\text { will drive Site-wide implementation of a scheduling/priority system for } \\
\text { work management. }\end{array}$} \\
\hline \multicolumn{4}{|c|}{ Description of what constitutes completion of this milestone: } \\
\hline \multicolumn{4}{|c|}{$\begin{array}{l}\text { This milestone will be completed by publication of a revision to the WHC- } \\
\text { CM-1-8 Work Management manual that includes the scheduling/priority system } \\
\text { developed for work management. }\end{array}$} \\
\hline \multicolumn{2}{|c|}{ 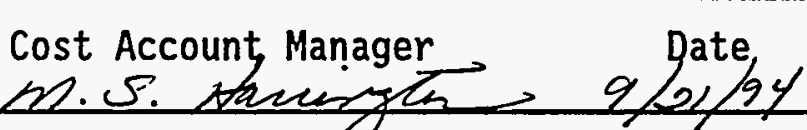 } & \multicolumn{2}{|c|}{ 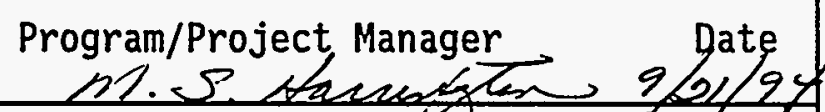 } \\
\hline \multicolumn{2}{|c|}{$\begin{array}{l}\text { Program Element Hanager } \\
\text { D.S. Haesesese, }\end{array}$} & DOE Monitor Pizen & $9 / 2,194$ Date \\
\hline
\end{tabular}


Title: Develop a third-party scheduling interface for the Job Control System software.

Date Prepared:

$8 / 15 / 94$

\begin{tabular}{|c|c|}
\hline WBS Designator: & 6.2 .2 .1 .1 \\
\hline Control Number: & MA-95-008 \\
\hline $\begin{array}{l}\text { Milestone Type: } \\
\square \text { DOE-HQ } \\
\square \text { DOE-RL } \\
\text { CNTR }\end{array}$ & $\begin{array}{l}\text { Division: } \\
\square \text { State } \\
\square \text { Federal } \\
\text { DOE } \\
\square \text { RCRA } \\
\square \text { TPA\# }\end{array}$ \\
\hline
\end{tabular}

\section{Milestone Description}

Developing a third party scheduling interface involves coding an interface between the $\mathrm{PX}_{0}$ scheduling software and the job control system scheduling tool.

Description of what constitutes completion of this milestone:

This milestone will be completed by release of a job control system program version incorporating third party scheduling.

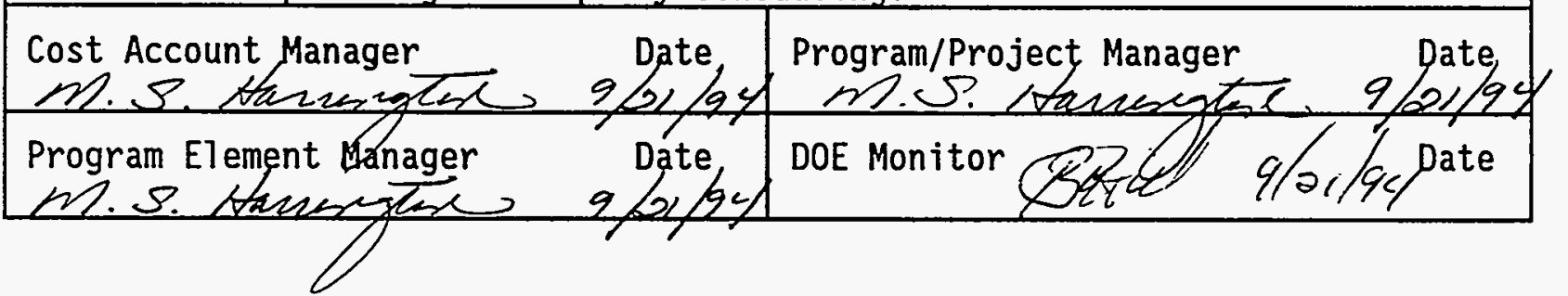




\begin{tabular}{|c|c|c|c|}
\hline \multicolumn{4}{|c|}{$\begin{array}{l}\text { Westinghouse Hanford Company } \\
\text { MILESTONE DESCRIPTION SHEET }\end{array}$} \\
\hline \multicolumn{3}{|c|}{$\begin{array}{l}\text { Title: Implement the combined work request form, } \\
\text { including fault codes for Equipment History }\end{array}$} & $\begin{array}{l}\text { Date Prepared: } \\
8 / 15 / 94\end{array}$ \\
\hline \multicolumn{3}{|c|}{ Assigned To: M. S. Harrington } & CIN: \\
\hline \multicolumn{3}{|c|}{ WBS Designator: $\quad 6.2 .2 .1 .2$} & $\begin{array}{l}\text { Due Date: } \\
6 / 30 / 95\end{array}$ \\
\hline \multicolumn{3}{|c|}{ Control Number: WMA-95-009 } & Revision: 0 \\
\hline $\begin{array}{l}\text { MiTestone Type: } \\
\square \text { DOE-HQ } \\
\square \text { DOE-RL } \\
\text { CNTR }\end{array}$ & $\begin{array}{l}\text { Division: } \\
\square \text { State } \\
\square \text { Federal } \\
\text { DOE } \\
\square \text { RCRA } \\
\square \text { TPA\# } \\
\end{array}$ & $\begin{array}{l}\text { Deliverable: } \\
\square \text { Report } \\
\square \text { Letter } \\
\square \text { Drawings } \\
\text { Other } \\
\text { (specify) } \\
\text { New JCS release }\end{array}$ & $\begin{array}{l}\text { Address to: } \\
\begin{array}{l}\text { DOE-HQ } \\
\text { DOE-RL } \\
\square \text { Other } \\
\text { (specify) }\end{array}\end{array}$ \\
\hline \multicolumn{4}{|c|}{ Milestone Description } \\
\hline \multicolumn{4}{|c|}{$\begin{array}{l}\text { Implementing the combined work request form, including fault codes, entails } \\
\text { writing the code to include this feature into the job control system } \\
\text { program. It will allow users, Site-wide, to extract causes for performing } \\
\text { corrective maintenance, facilitating the creation of an equipment history. }\end{array}$} \\
\hline \multicolumn{4}{|c|}{ Description of what constitutes completion of this milestone: } \\
\hline \multicolumn{4}{|c|}{$\begin{array}{l}\text { This milestone will be completed with the release of a job control system } \\
\text { software version implementing a single work request form and including } \\
\text { fault codes for equipment history tracking. }\end{array}$} \\
\hline \multicolumn{2}{|c|}{ 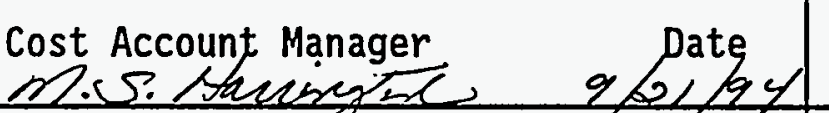 } & \multicolumn{2}{|c|}{ Program/Project Manager } \\
\hline \multicolumn{2}{|c|}{$\begin{array}{l}\text { Program Element Manager } \\
\text { M.S. Date }\end{array}$} & \multicolumn{2}{|c|}{ DOE Monitor BKEL/ $9 / \sigma_{1} / 94$ Date } \\
\hline
\end{tabular}


4.0 TARGETED FUNDING IMPACTS TO PLANNED ACTIVITIES 


\subsection{Targeted Funding Program Impacts}

Targeted funding is approximately $\$ 350,000$ less than originally proposed in Sections 1 through 3 of this document. The following reductions were made to the original proposal.

\begin{tabular}{|c|c|c|}
\hline $\begin{array}{c}\text { Cut } \\
(s, 000 \text { s })\end{array}$ & Funding Category & Funding Loss Impact \\
\hline 27.0 & $\begin{array}{c}\text { Computer Hardware } \\
:\end{array}$ & $\begin{array}{l}\text { Potential inability to maintain the Job } \\
\text { Control System (JCS) in acceptable } \\
\text { operating condition. Loss of JCS hardware } \\
\text { reliability could impact the ability of } \\
\text { affected facilities to adequately plan, } \\
\text { schedule, and track work. }\end{array}$ \\
\hline 10.0 & $\begin{array}{l}\text { Off Site training } \\
\text { and travel expense }\end{array}$ & $\begin{array}{l}\text { Off Site training allows personnel to } \\
\text { learn skills not taught on Site. As } \\
\text { important as the training, this cut limits } \\
\text { interface with industry. This isolation } \\
\text { further insulates the Hanford Site Work } \\
\text { Control process from industry standards. }\end{array}$ \\
\hline 152.3 & $\begin{array}{l}\text { Purchase contracts } \\
\text { and associated } \\
\text { internal overhead } \\
\text { costs }\end{array}$ & $\begin{array}{l}\text { Loss of these funds decreases the amount } \\
\text { of consultant time for Hork Control and } \\
\text { schedul ing training and mentoring. This } \\
\text { area is attributed with much success in } \\
\text { Fiscal Year } 1994 \text {. It decreases the Kappes } \\
\text { Consulting contract from } 12 \text { months to } 10 \\
\text { months and the PSDI contract from } 12 \\
\text { months to } 6 \text { months. Also unfunded are the } \\
\text { software and hardware required to pilot } \\
\text { the Maximo software in TWRS. This loss of } \\
\text { funding removes Milestone WMA-95-006 from } \\
\text { the list of FY } 1995 \text { Milestones. }\end{array}$ \\
\hline 22.1 & $\begin{array}{l}\text { Operations } \\
\text { Assurance personnel } \\
\text { matrix }\end{array}$ & $\begin{array}{l}\text { These funds were to support the reporting } \\
\text { of Performance Measurements to RL by } \\
\text { funding a Statistical Process Control } \\
\text { Engineer. }\end{array}$ \\
\hline 94.1 & $\begin{array}{l}\text { Procedure } \\
\text { Development/Control } \\
\text { personnel matrix }\end{array}$ & $\begin{array}{l}\text { These funds were to support creation of } \\
\text { Workmanship standards for the Site. }\end{array}$ \\
\hline 12.9 & $\begin{array}{l}\text { Media Service } \\
\text { Center personnel } \\
\text { matrix }\end{array}$ & $\begin{array}{l}\text { These funds were to support editing and } \\
\text { producing the many documents this program } \\
\text { produces. }\end{array}$ \\
\hline 29.6 & BCSR & $\begin{array}{l}\text { These funds supported the finding of a } \\
\text { commercial work management software } \\
\text { package to replace the Job Control System }\end{array}$ \\
\hline 348.0 & $\begin{array}{l}\text { TOTAL CUT FROM } \\
\text { PLANNED PROGRAM }\end{array}$ & \\
\hline
\end{tabular}


FUNDING REDUCTION IMPACT SUMMARY:

1. Funds for development of workmanship standards was reduced by $100 \%$.

2. Milestone HMA-95-006, Complete a TWRS pilot of the Maximo software, will not be performed.

3. Reduction in support to the Work Management manager training and mentoring program.

4. Reduction in support of the basic scheduling training activity.

5. Reduction in JCS hardware support. 


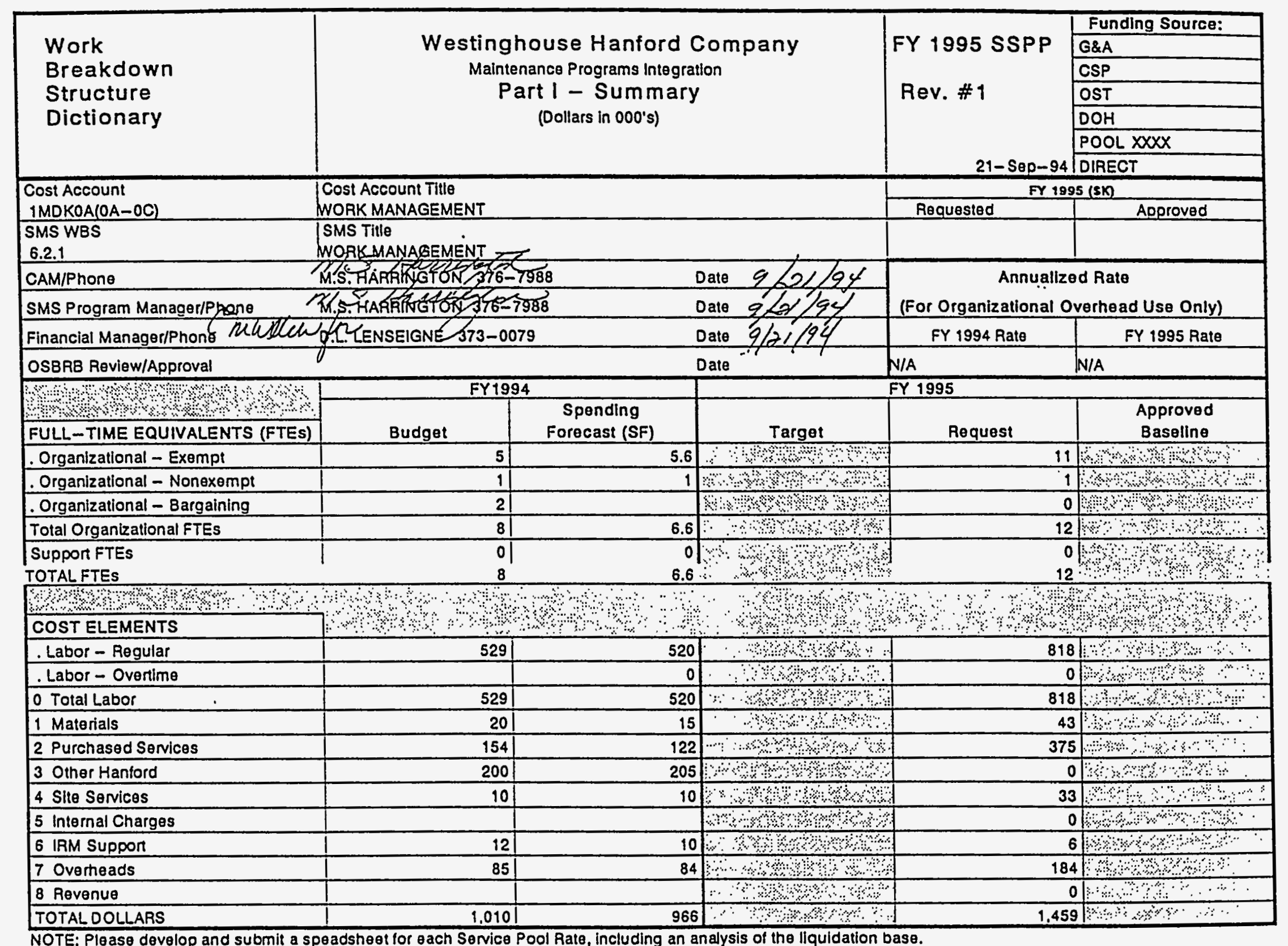

NOTE: Please develop and submit a speadsheot for each Service Pool Rate, including an analysis of the liquidation base. othuptorm 
WHC-SP-1127

\begin{tabular}{|l|c|c|}
\hline $\begin{array}{l}\text { Work Breakdown } \\
\text { Structure } \\
\text { Dictionary }\end{array}$ & Westinghouse Hanford Company & FY 1994 SSPP \\
REV. \#1 & Maintenance Program Integration \\
\hline
\end{tabular}

\begin{tabular}{|c|c|c|}
\hline \multicolumn{2}{|l|}{$\begin{array}{l}\text { WORK BREAKD OWN STRUCTURE DICTIONARY } \\
\text { PART II - ELEMENT DEFINITION }\end{array}$} & $\begin{array}{l}\text { WBS ELEMENT CODE: } 6.2 .1 \\
\text { TITLE: WORK MANAGEMENT } \\
\text { CONTRACTOR: WHC }\end{array}$ \\
\hline INDEX LINE NO. & REVISION NO. AND AUTHORIZATION & DATE \\
\hline \multicolumn{3}{|l|}{ APPROVED CHANGES } \\
\hline $\begin{array}{l}\text { SYSTEM DESIGN DESCAIPTION } \\
\text { NUMBER: } \\
\text { TITLE: }\end{array}$ & FUNDING DOCI & \\
\hline \multicolumn{3}{|c|}{$\begin{array}{l}\text { COST CONTENT - } \\
\text { The Work Management element operates using the Westinghouse Hanford Company and ICF - KH self liquidating pool concept. This budget source funds } \\
\text { technical engineering support to maintenance integration activities required to support site Work Management, consulting and mentoring services, } \\
\text { administration of Davis-Bacon and administration costs for Work Management. }\end{array}$} \\
\hline \multicolumn{3}{|c|}{$\begin{array}{l}\text { The Work Management element to the WHC Maintenance Administration Program provides lechnical and administrative suppon to the operation of several } \\
\text { sitewide maintenance processes. Work Management supports WHC sitewide implementation and compllance with DOE 4330.4B, Maintenance Management } \\
\text { Program. Work Management element suppons coordination and development of the Site Maintenance Plan, } \\
\text { The Work Management elemeasurent provides and coordinates consudget Submittal, and the sitewide WHC Maintenance Program Policy and Procedure Manuals. } \\
\text { The Work Management element also reviews and approves all Work Management and JCS ADP training odeveloped by Technical Training for end users. }\end{array}$} \\
\hline \multicolumn{3}{|l|}{$\frac{\text { OBJECTIVES - }}{\text { Seo attached pages. }}$} \\
\hline \multicolumn{3}{|l|}{$\frac{\text { ASSUMPTIONS/CONSTRAINTS }}{\text { Se日 attached pages. }}$} \\
\hline
\end{tabular}




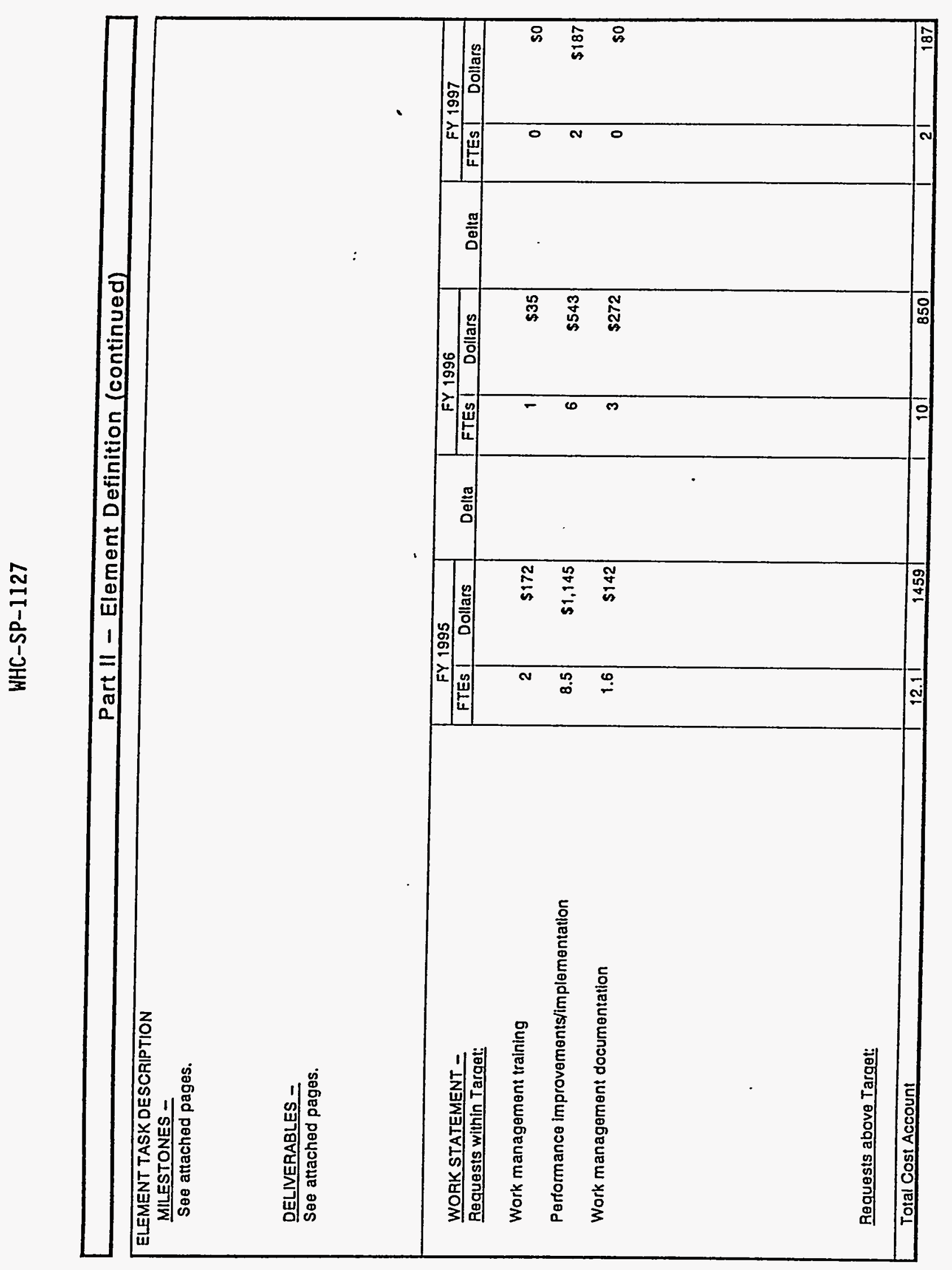

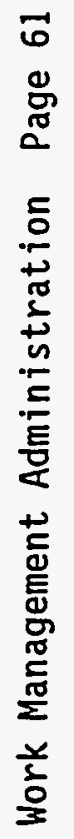


WHC-SP-1127

\section{ADDENDUM TO WORK BREAKDOWN STRUCTURE DICTIONARY}

FOR WBS 6.2.1, WORK MANAGEMENT

\section{OBJECTIVES}

\section{Objective 1}

Define process and measurements needed to implement work management.

Goals:

1) Take leadership role in establishing EPS

- Develop an implementation plan for adopting NAVFAC EPS

- Tailor EPS to individual plants

- Integrate EPS with-workmanship-standards

- Integrate EPS factors into training

2) Take leadership role-in-stablishing workmanship-standards

- Pilot issue workmanship-standards

- Establish consistent site training of workmanship-standards with the Fechical Training organization

- Coopdinate training for using workmanship standards with the

Fechnical Training Organization

3) Establish work scheduling guidance that fulfills program objectives and publish in WHC-CM-1-8 Site-wide manual

- Establish an integrated priority system meaningful to Site operations in support of work management Site objectives

- Run a pilot program in TWRS

4) Establish guidance for developing uniform plant M\&IPs for nuclear facilities

- Publish guidance for the M\&IPs, with plant involvement

- Incorporate guidance for using SELs and MELS

5) Incorporate SEL and MEL guidance into HHC-CM-1-8, Work Management

6) Re-evaluate-Site-work management performance measures in terms of equipent availability

7) Update Part 2 of the Site Maintenance PIan for 1995 maintenance activities

8) Define standards for equipment history (fault codes for equipment failure). Publish in WHC-CM-1-8, Work Management.

\section{Objective 2}

Define the training needed to communicate the Work Management process. 


\section{Goals:}

1) Extend the Kappes Consulting contract through October 1995 for continued Work Management training and mentoring. As a minimum, mentoring in field will focus on support to the plants in the following areas:

- Suggested supervisor time in the field

- Establishing optimum performance objectives

- Pre-release process delays

- Post-release suspension rate

- $\quad$ Adherence to the schedule

2) Ensure the basic scheduler training need is met by reviewing Project Software and Development, Inc. scheduler training results. Extend, modify or replace based on results.

3) Continue administration of Davis-Bacon Compliance activities. Provide additional assistance in the following areas:

- Provide Davis-Bacon training

- Make the computer-based training course (in ToolBook) available to the Site on Davis-Bacon file server

- Hrite the desk instruction for preparing plant forces work reviews

- Add new examples of plant forces work reviews to those already available on the Davis-Bacon file server

- Expand the Area Work Review Agent (AWRA) base to include Radio Maintenance, Security Maintenance, Boeing Computer Services Maintenance, Telecommunications, Projects and Facilities Management. (This includes getting AWRA's assigned and providing the required training.)

4) Continue review input and support of the work management training, coordinated with the Technical Training organization

5) Coordinate development and review/approve all JCS training provided by the Technical Training organization

\section{Objective 3}

Provide mentoring work management for work control centers.

\section{Goals:}

1) Provide personnel to advise facility personnel on Work Management issues associated with the process, associated data processing or procedures manual.

2) Provide assistance to field personnel to optimize work package processes

3) Communicate lessons learned and good practices observed to facilitate most effective Work Management practices.

\section{Objective 4}

Document the Work Management Process. 


\section{Objective 5}

Provide resolution to plant specific and Sitewide work management issues raised in FY 1995.

\section{Objective 6}

Continue coordinating plant implementation of the JCS preventive maintenance/surveillance and equipment history modules in accordance with established schedule.

\section{Objective 7}

Evaluate the need and make recommendations to replace the JCS software program with a commercial work management program

\section{Goals:}

1) Establish the minimum operating criteria for a work management computer program to meet site needs.

2) Review open market work management products to obtain the most cost effective computer software system to meet the established criteria.

3) Pilot and implement the.selected-software-package.

\section{Objective 8}

Continue to streamline work initiation and release processes to support smoother transition to commercial software application selected to replace existing JCS.

\section{ASSUMPTIONS/CONSTRAINTS}

1) Site Procedures group will maintain responsibility for interfacing with user groups relative to statutory permits.

2) Completion/closure of work packages is the responsibility of the facility owners/managers.

3) Work management will continue to improve at a pace that will allow this program to dissolve by FY 1997.

4) Customer support for implementing EPS will continue throughout the implementation effort.

5) Naval Facilities Engineering Command personnel will be available to support implementation of EPS.

6) We can use a high percentage of the material developed by NAVFAC for ICF KH.

7) There will-be continued-support and-funding-for developing-wopkmanship standards. 
8) There wi77 be continued matrix support from Procedures Development, Tank Haste Remediation Services, Technical Training and the-Erafts.

9) Reorganizations will trigger a revision to the Site Maintenance Plan, Part 1.

10) There will be adequate support to drive development of a planning and scheduling manual.

11) There will be a sponsor to pilot a planning and scheduling system to be included in a manual.

12) The Work Management Sub-Council will sponsor FY 1996 implementation of a planning and scheduling manuat.

13) There will be adequate contract support to assist with development of a planning and scheduling manual.

14) There will be elements of the old WHC-CM-8-8 manual that will need to be included in the WHC-CM-1-8 manual.

15) Kappes Consulting will be available to support Work Management Implementation through October 1995.

16) Groups targeted to assign Area Work Review Agents will support their assignment.

17) There will be continued customer support for a single work form to initiate and conduct work to aid in streamlining the work management process.

18) The $4 A X I M 0$ program, produced by PSOI, wi77-adequately peplace the-JCS and be compatible with the network.

19) The MAXIM0 program-ean-be readify-obtained for-a-Tank-Waste-Remediation Systems pilot program.

20) There will be continued support to adopt single work release form methodology.

Any item on the list of assumptions could conceivably become an issue and constrain the program. The Hork Management Administration Program has the potential to be constrained by change in senior management objectives or Tack of funding due to decreases in congressional support for the Hanford site.

\section{ELEMENT TASK DESCRIPTION}

\section{Milestones}

- Develop a work management ADP specification document for commercial software in support of pursuing replacement of current JCS software by $10 / 31 / 94$.

- $\quad$ Replace $38 / 39$ with single form by $6 / 30 / 95$. 
WHC-SP-1127

- Place contract for NAVFAC Services by $11 / 30 / 94$.

- Develop a plan for scheduling/priority system installation by $2 / 28 / 95$.

- Pilot, evaluate \& adjust scheduling process by $6 / 1 / 95$.

- Revise WHC-CM-1-8 to incorporate results of scheduling pilot by $9 / 30 / 95$.

Pilot Maximo commercial work magement softwape-in- THRS by 6/30/95.

\section{Deliverables}

- Issue firm schedule for implementation of the JCS PM/S module by $12 / 31 / 94$.

- Pilot single work request/initiation form by $12 / 31 / 94$.

- Develop Site training for use by $12 / 31 / 94$.

- Revise WHC-CM-1-8 to include changes in draft by $12 / 31 / 94$.

- Implement use of form and issue manual change by $4 / 31 / 95$.

- Put Tool Book on Davis-Bacon file server by 10/31/94.

- Provide Davis-Bacon awareness training to Radio Maintenance, Security Maintenance, BCSR Maintenance, Telecommunications, Projects, Facility Management and Procurement by .9/31/95

- Establish Area Work Review Agents for these organizations by 9/31/95.

- Update Site Maintenance Plan Part 2 by $4 / 15 / 95$.

- Define standards for equipment history fault codes by $1 / 31 / 95$.

- Develop implementation plan for NAVFAC work by $11 / 30 / 94$.

Issue-workmanship-standards update and-cordinate training on a quarter $7 y$ setredute.

- Create Site guidance for developing consistent M\&IPs (incorporate importance of SEL/MEL) by 10/31/94.

- Conduct workshop to investigate the feasibility of incorporating RWP and Lock \& Tag into the WHC-CM-1-8 procedure by $6 / 31 / 95$.

- Extend Joe Kappes Consulting contract (for continued mentoring support to end users) by 10/31/94. 


\begin{tabular}{|c|c|c|c|c|c|}
\hline \multirow{7}{*}{$\begin{array}{l}\text { Work } \\
\text { Breakdown } \\
\text { Structure } \\
\text { Dictionary }\end{array}$} & \multirow{7}{*}{\multicolumn{3}{|c|}{$\begin{array}{l}\text { Westinghouse Hanford Company } \\
\text { Maintenance Programs Integration } \\
\text { Part I - Summary } \\
\text { (Dollars in 000's) }\end{array}$}} & \multirow{7}{*}{$\begin{array}{r}\text { FY } 1995 \text { SSPP } \\
\text { Rev. \#1 } \\
21-\text { Sep }-94_{1}\end{array}$} & \multirow{4}{*}{\begin{tabular}{|l|} 
Funding Source: \\
G\&A \\
CSP \\
OST \\
\end{tabular}} \\
\hline & & & & & \\
\hline & & & & & \\
\hline & & & & & \\
\hline & & & & & $\mathrm{DOH}$ \\
\hline & & & & & POOLXXX \\
\hline & & & & & DIRECT \\
\hline Cost Account & Cost Account Titie & & & Fr 1995 & $5(\$ K)$ \\
\hline 1MDKOA $(O D-O F)$ & JOB CONTROL SYSTEM & & & Requested & Approved \\
\hline $\begin{array}{l}\text { SMS WBS } \\
6.2 .2 \\
\end{array}$ & $\begin{array}{l}\text { SMS TItl } \\
\text { JOB CONTROL SYSTEM }\end{array}$ & & & & \\
\hline CAM/Phone $\quad 2 / 4$ & 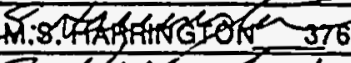 & & Date: $9 / 21 / 1$ & Annualizec & d Rate \\
\hline SMS Program Managey/Phone $\mathrm{H} / \mathrm{H}$ & 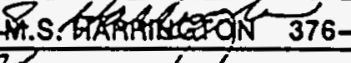 & & Date: $\& / 2 / 8$ & (For Organizational Ov & verhead Use Only) \\
\hline 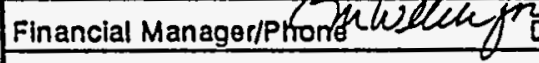 & D.L. LENSEIGAKE $373-00$ & & Date: $9 / 21 / 94$ & FY 1994 Rate & FY 1995 Rate \\
\hline OSBRB Revlew/Approval & & & Date & N/A & N/A \\
\hline & FY199 & & & FY 1995 & \\
\hline $\begin{array}{l}\text { S } \\
\text { FULL-TIME EQUIVALENTS (FTES) }\end{array}$ & Budget & $\begin{array}{c}\text { Spending } \\
\text { Forecast (SF) }\end{array}$ & Target & Request & $\begin{array}{c}\text { Approved } \\
\text { Baseline }\end{array}$ \\
\hline . Organizational - Exempt & 2 & 26 & $\therefore \%+4 \times 4$ & 0 & Pa: : $: 4$ \\
\hline . Organizational - Nonexempt & & & $\mathrm{Bms} \times \mathrm{Bn}$ & $\therefore 0$ & Onds. \\
\hline . Organizational - Bargaining & & & $-3+$ & 0 & m \\
\hline Total Organizational FTEs & 2 & 2 & 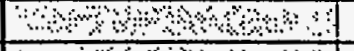 & 0 & an, $40 \%$ \\
\hline SUpport FTEs & 101 & 10.5 & চ४ওিক & 6.8 & 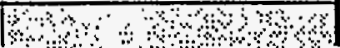 \\
\hline TOTALFTES & 12 & 12.5 & 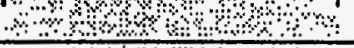 & 6.8. & +u,, $4 \%$ \\
\hline & १४४ & & 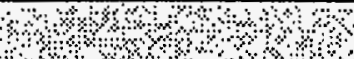 & & केष \\
\hline COST ELEMENTS & & & & & m \% \\
\hline . Labor - Regular & 806 & 761 & 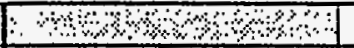 & 477 & $\because \cdots \cdots \times$ \\
\hline . Labor - Overtime & 0 & 4 & - & 0 : & nom \\
\hline 0 Total Labor & 806 & 765 & $\because \%, \%$ & $477:$ & 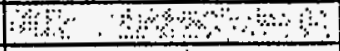 \\
\hline 1 Materials & 109 & 151 & 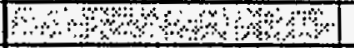 & 0 & 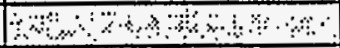 \\
\hline 2 Purchased Services & 150 & 70 & $\because n+4,4 \%$ & 0 & 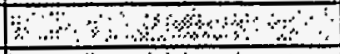 \\
\hline 3 Other Hanford & 5 & 20. & कम यमा & 0 & $10 \% \%+4 \times$ \\
\hline 4 Site Services & 0 & 41 & ân, & 0 & क्य \\
\hline 5 Internal Charges & 0 & 9 & 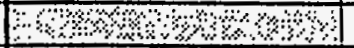 & 0 & 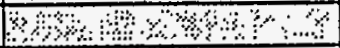 \\
\hline 6 IRM Support & 0 & 46 & +4\%, & 01 & का \\
\hline 7 Overheads & 431 & 394 & की & 107 & Weकी की की \\
\hline 8 Revenue & & 0 & 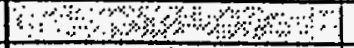 & 0 & कa" \\
\hline TOTAL OOLLARS & 1.501 & 1.496 & Hoxh & 584 & $\therefore \%$ mom \\
\hline
\end{tabular}

NOTE: Ploase devalop and submit a speadsheot for each Service Pool Rate, including an anaysis of the liquidation base.

o:tyuptorm 
WHC-SP-1127

\begin{tabular}{|l|c|c|}
\hline $\begin{array}{l}\text { Work Breakdown } \\
\text { Structure } \\
\text { Dictionary }\end{array}$ & $\begin{array}{c}\text { Westinghouse Hanford Company } \\
\text { Maintenance Programs Integration } \\
\text { Part II - Element Definition }\end{array}$ & FY 1995 SSPP \\
REV. \#1 & REV \\
\hline
\end{tabular}

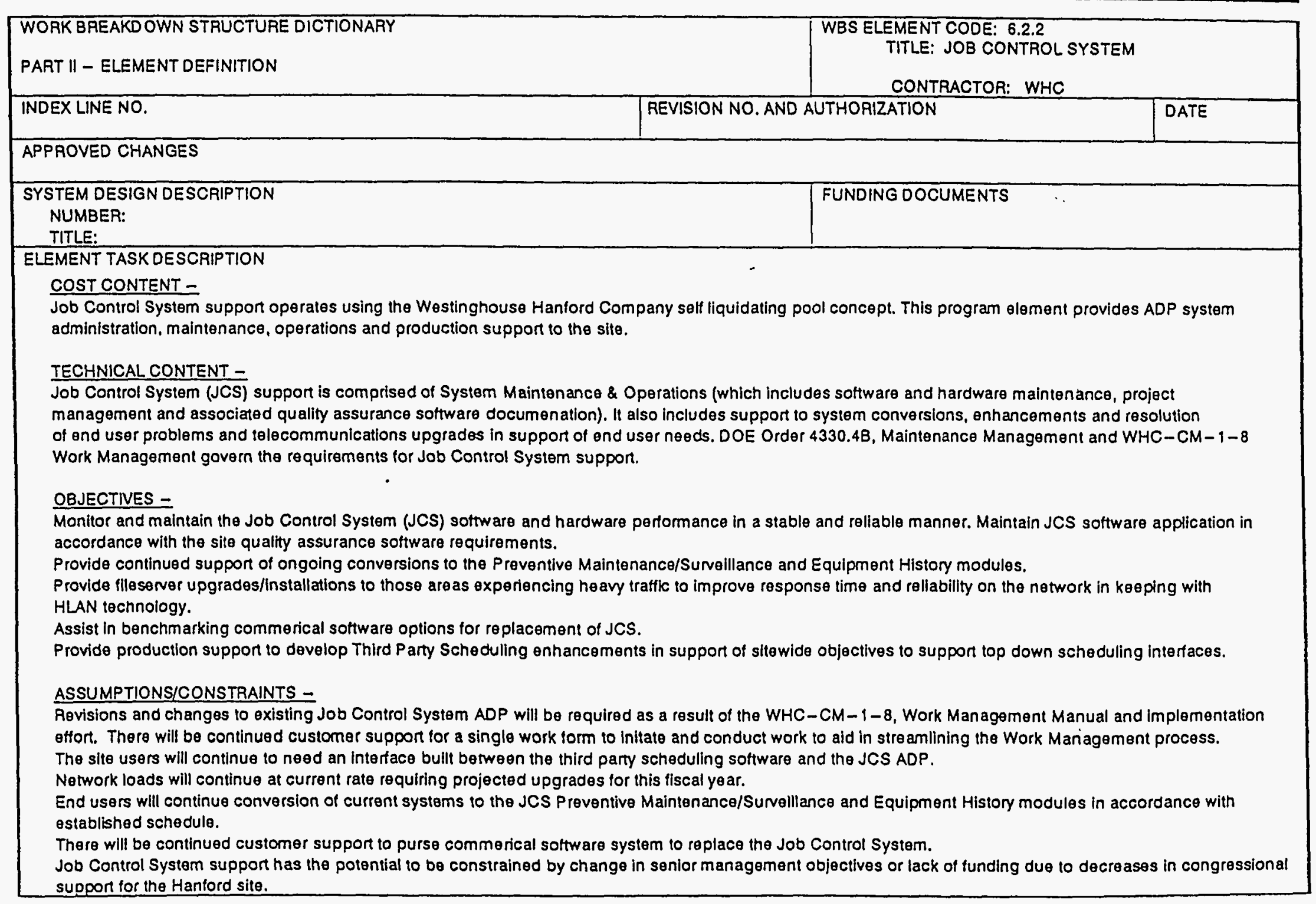

Work Management Administration 


\section{Part II - Element Definition (continued)}

ELEMENT TASK DESCRIPTION

MILESTONES -

Develop Third Party Scheduling Interface with site scheduling software and the JCS ADP software. 12/31/94

Develop Single Form Work Request including fault codes for Equipment History. 06/30/95

DELIVERABLES -

Separate the 222-S Laboratory data from WESCF data. This will be accomplished by installation of new flleserver. 12/31/94

Develop data table for end users to extract perfomance measurement data. 01/31/95

Install 6 new fileservers to improve JCS network operations in the following areas: Electrical Utilities, 222-S/WESCF, FFTF/MASF/IEM Cell, Solid Waste, and 300 Treated Effluent Facillty. 06/30/95.

WORK STATEMENT -

Requests within Target:

Maintenance and Operations of the Job Control system plus non-labor costs

Provide system hardware/sottware improvements

Off shelf work management software

Requests above Target: 


\section{DISTRIBUTION}

Number of Copies

ONSITE

2 U.S. Department of Energy, Richland Operations Office

B. E. Hill

J. E. Mecca

14 Westinghouse Hanford Company

Correspondence Control

A3-01

President's Office

B3-01

E. Alford

G6-14

W. T. Alumkal

S7 -85

K. D. Cameron

A5- 04

H. P. Fox

R2 -88

L. R. Hafer

B3 -75

N. S. Hale

B4 -53

M. S. Harrington

B4 -53

J. L. Lee

C. L. Stice

S7-82

Central Files

G7 -20

OSTI (2)

L8-04

A3-36 